\title{
Structural and hydrothermal alteration mapping related to orogenic gold mineralization in part of Kushaka schist belt, North-central Nigeria, using airborne magnetic and gamma-ray spectrometry data
}

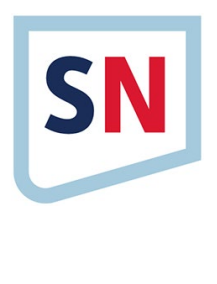

\author{
Sherif Olumide Sanusi ${ }^{1} \cdot$ John Olurotimi Amigun ${ }^{1}$
}

Received: 23 April 2020 / Accepted: 26 August 2020 / Published online: 30 August 2020

(c) Springer Nature Switzerland AG 2020

\begin{abstract}
This paper presents an interpretation of airborne magnetic and gamma-ray spectrometry data over a part of the Kushaka schist belt of Nigeria with a view to assess the sub-surface structural framework and hydrothermal alteration haloes that are related to orogenic gold mineralization in the study area. The geophysical analyses performed to improve the quality of the aeromagnetic data for better understanding of the subsurface geology were reduction to the equator, upward continuation, total horizontal derivative, analytical signal, source edge detection, tilt-angle derivative of total horizontal derivative. The analyses performed on the airborne gamma-ray spectrometry data were made on $\mathrm{K} / \mathrm{eTh}, F$ parameter and deviation of ideal $\mathrm{K}$ values $(\mathrm{Kd})$. Deep-seated, brittle-ductile shear/fracture zones with characteristic depth of $428.0-607.6 \mathrm{~m}$ and area extent of $15.5 \mathrm{~km}$ by $6.5 \mathrm{~km}$ that were delineated in the area coincide with beehive of artisanal miners exploiting gold deposits. In this study, subsurface geologic structures, specifically dykes/faults, that trend in the ENE-WSW direction constitute a first-order control on orogenic gold mineralization in the study area. The hydrothermally altered zones mapped in the area indicated they are structurally controlled and closely associated with orogenic gold mineralization. Apart from geologic structural evidences that are controlling orogenic gold mineralization, this study has indicated that hydrothermal alteration mapping is equally important for a promising orogenic gold mineralization mapping.
\end{abstract}

Keywords Structural framework - Orogenic gold mineralization · Hydrothermal alteration · Aeromagnetics · Aeroradiometrics $\cdot$ Kushaka schist belt

\section{Introduction}

The Gurara area (Fig. 1), situated in the Kushaka schist belt of north-central Nigeria, has been reported to be associated with gold mineralization in stream sediments (alluvial), soil sediments (eluvial), and within geologic structures and quartz veins [1]. Although approximately $90 \%$ of Nigeria's total gold production is from alluvial and eluvial deposits [2], it is equally important to consider the orogenic gold mineralization in the Kushaka schist belt from which both the alluvial and eluvial deposits originated.
One of the critical factors controlling orogenic gold mineralization in the Kushaka schist belt and in some other schist belts in Nigeria (Maru, Anka, Zuru, Zungeru-Birnin Gwari, Karaukarau, Ilesa, Iseyin-Oyan and Egbe-Isanlu schist belts) is the geologic structure. These structures are significantly involved in the migration, remobilization and localization of primary gold deposits [1-4]. Delineation of these crustal-scale structures such as dykes, faults, shear zones, folds, joints, and lithological contacts is pivotal in exploration targeting program. Most often, geologic structures provide conduits for the migration of deep-occurring

Sherif Olumide Sanusi, sanusisherif13@gmail.com; sosanusi@futa.edu.ng| ${ }^{1}$ Department of Applied Geophysics, Federal University of Technology, Akure, Nigeria. 


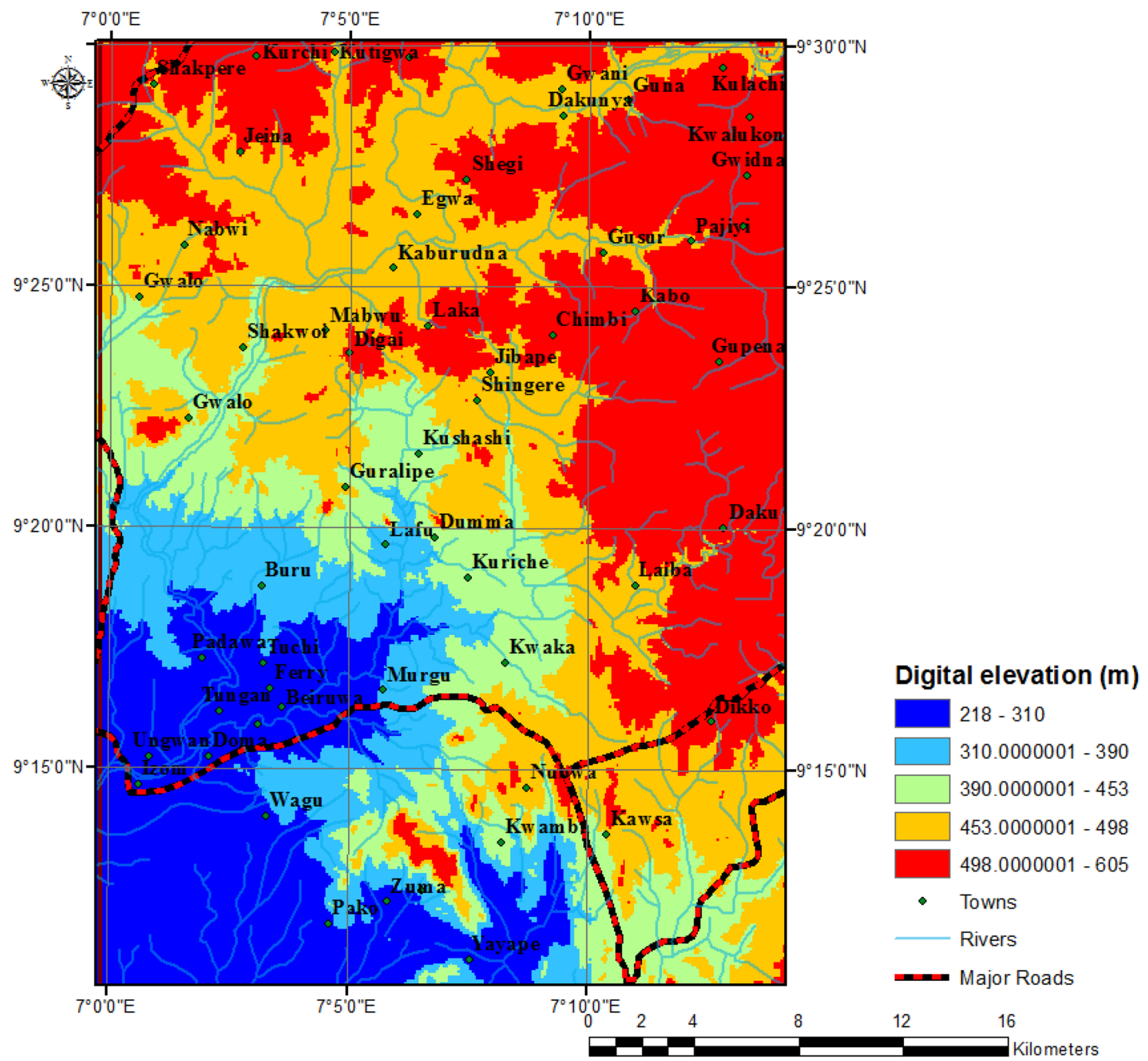

Fig. 1 Digital ground elevation model of the Gurara area

hydrothermal mineralizing fluids to higher crustal levels and in the process, fluid-rock interaction for gold thiosulfate complex precipitation and localization is enhanced $[3,5-10]$. Structural controls are not only very vital to gold mineralization but also the hydrothermal alteration processes $[6,7,11-14]$.

Even though geologic structures are critical to orogenic gold mineralization in the Kushaka schist belt and in other orogens in the world, it is not all geologic structures that exist in a geologically permissive field that are mineralized [15]. The manifestation of hydrothermal alteration haloes in a genetically endowed setting like the study area is an indication that auriferous mineralizing fluid has traversed through the geologic structures and deposited gold minerals $[11,16]$. Prospecting for hydrothermal alteration zones suggests exploring areas with favourable geologic structural sites within the crustal levels that could provide conduits for hydrothermal fluids. The hydrothermal fluids that are composed of water, silica, sulphide and chlorine compounds, carbonates, and ions of potassium, sodium, calcium, iron and magnesium [7, 16-21] migrate through the tectonically deformed rocks to precipitate precious metal like gold. The hydrothermal fluid constituents involved in the following alteration types: prophyllitic (occurs in form of epidote, i.e. $\mathrm{Al}_{2} \mathrm{Si}_{4} \mathrm{O}_{10}(\mathrm{OH})_{2}$ ), potassic (occurs mainly as muscovite, $\mathrm{KAl}_{3} \mathrm{Si}_{3} \mathrm{O}_{10}(\mathrm{OH})_{2}$ ), phyllic 
(occurs as sericite, i.e. $\mathrm{KAl}_{2}\left(\mathrm{AlSi}_{3} \mathrm{O}_{10}\right)(\mathrm{OH})_{2}$ ) alterations and silicification (occurs in form of amorphous silica or quartz, i.e. $\mathrm{SiO}_{2}$ ) are often associated synchronously with orogenic gold mineralization [14].

The application of airborne geophysical methods such as airborne magnetic, gravity, electromagnetic and radiometric to gold mineralization mapping has been proven to be efficient and effective in mapping targeting elements that are related to orogenic gold mineralization $[1,6,7$, $11-13,22]$. The standard processing of geophysical data can be used to delineate mineralization expressions that are not commonly visible during surface geological mapping due to the presence of dense vegetation cover, thick soil cover, size of outcrops and non-existence of surficial manifestations of mineralization footprints [23-30]. Hence, the integration of appropriate geophysical methods for mapping geologic structures and hydrothermal alteration haloes in relation to orogenic gold mineralization can assist in maximizing prospecting benefits $[22,28,30]$, rather than solely relying on field geological mapping.

The potential fields of the earth, most especially aeromagnetic method, are well known as an important source of information for studying sub-surface structural framework of basement rocks [6, 8, 22, 30-32]. Aeromagnetic data is not only limited to delineating structural fabrics of tectonically deformed basement rocks, but it is also a veritable tool in investigating magnetomineralogical changes that are related to syn-mineralization hydrothermal alteration subsystem $[7,11,26]$.

Apart from the magnetic mineralogy changes, identification of radioelement concentration changes as a result of hydrothermal alteration processes is equally important in mapping auriferous mineralization potential zones. Conventionally, potassium enrichment and thorium impoverishment (as a result of thorium geochemical immobility) are spatially associated with hydrothermal alteration specifically, prophylitic, phyllic and potassic alterations [16, 19-21, 25, 33-35]. Epidote, a by-product of prophylitic alteration, contains traceable amounts of rare earth elements, particularly potassium, thorium (eTh) and uranium (eU) radioelements [36]. Quartz minerals, that are associated with silicification, formed at the late magmatic crystallization sequence; hence, they are enriched in potassium $\left({ }^{40} \mathrm{~K}\right)$ [4-6]. Airborne gamma-ray spectrometry data offers a three-element geochemical image of the prospective area from the red-green-blue (RGB) composition of potassium (K), thorium (eTh) and uranium $(\mathrm{eU})$ radioelements, and may better reflect structural and hydrothermal alteration footprints than the field observations $[11,12,21$, 26]. Thus, it is possible to provide a realistic guide for future investments through the mapping of geologic structures and hydrothermal alteration zones using airborne magnetic and radiometric data $[1,7,20,21,29,30,37]$. In this study, aeromagnetic and airborne radiometric surveys are used as a veritable tool to map geologic structures and hydrothermal alteration zones that could promote orogenic gold mineralization in the Gurara area.

\section{Geologic setting and mineralization}

The Gurara area is bounded by latitudes $9^{\circ} 10^{\prime} 40^{\prime \prime} \mathrm{N}-9^{\circ}$ $30^{\prime} 00^{\prime \prime} \mathrm{N}$ and longitudes $6^{\circ} 59^{\prime} 48^{\prime \prime} \mathrm{E}-7^{\circ} 14^{\prime} 06^{\prime \prime} \mathrm{E}$ (Fig. 1). It is situated at the southern border of the Kushaka schist belt (Fig. 2). The Kushaka schist belt is well explored like any other schist belts in Nigeria, because it is associated with economic concentrations of gold and other accessory minerals $[2,38]$.

The Kushaka schist belt developed in Neoproterozoic age is composed mainly of low-grade meta-volcanosedimentary rocks and minor granite rocks $[38,40]$. The inference from isotopic dating shows that the schist belt was developed between $1100 \mathrm{Ma}$ (Kibaran) and $600 \mathrm{Ma}$ (Pan-African) age [2, 39]. Similarly, the isotopic dating of the syn-to-late tectonic intrusive granite rocks that are present in the schist belt matches the window of PanAfrican (750-500 Ma) orogeny event [39]. The emplacement of the orogenic gold mineralization in the area, on the basis of structural relationships, is considered to occur at the Late Pan-African (500 Ma) orogeny event [4, 38]. The time window for orogenic gold mineralization occurred after granitoid intrusion, regional metamorphism, and fracturing episodes in the belt. It has been reported that gold-bearing quartz veins and stockworks in the Kushaka schist belt are accommodated in greenschist, pyllites and gneisses, and they often occur with sulphide minerals such as pyrite, molybdenite, chalcopyrite, galena, covellite and chalcocite [38]. The passage of hydrothermal-auriferous fluids in the belt is principally controlled by the conjugate fault system (i.e. NE-SW dextral transcurrent fault and subsidiary NW-SE faults) $[1,5,38,41]$. The emergence of the conjugate fault system in the belt stemmed from the uplift and ductile-brittle deformation at the Late Pan-African orogeny $(530 \mathrm{Ma})$ age $[1,38]$.

The lithological units in the area composed of undifferentiated schist, migmatite gneiss, porphyroblastic gneiss, granite gneiss, quartz veins, amphibolites, and pegmatites (Fig. 3). The southeastern flank of the investigated area is composed of migmatite gneiss, and the wider portion in the south is underlain by granite gneiss. Porphyroblastic gneiss occurs predominantly at Gurara, Tuchi, Guralipe and Murgu and is expressive at diverse locations in the area [42]. The orientation of most of the lithological units in the area is in the NE-SW direction. Geologic structures such as veins, faults, joints, folds, dykes, and foliations proliferate some of the lithologies in study area [1]. Swarms of 


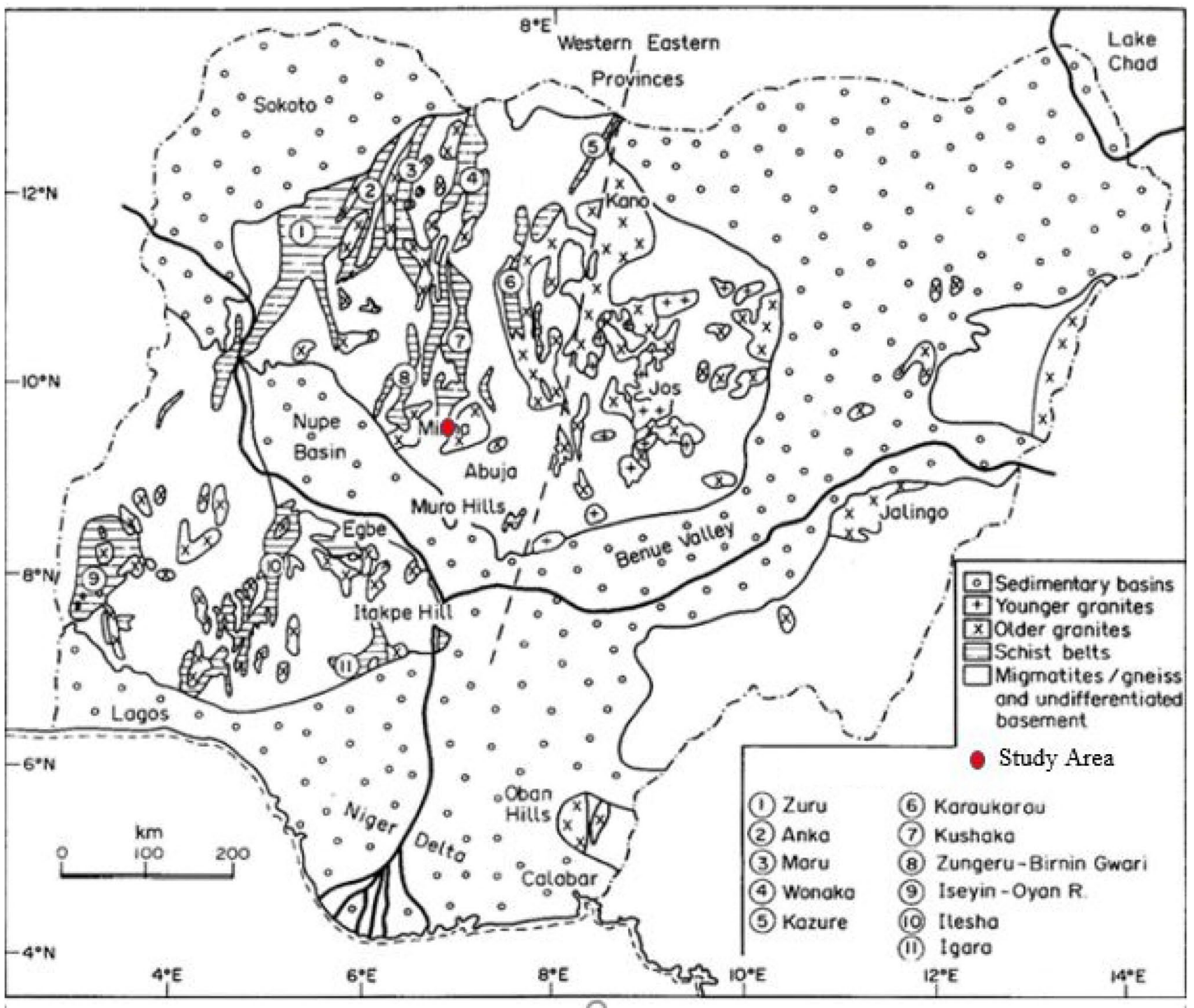

Fig. 2 The geological map showing the Nigerian schist belts (modified after Woakes et al. [83])

dolerite dykes cross-cut some of the outcrops at the northern part of the study area and are considered conduits through which mineralizing fluids traversed to deposit gold minerals. The manifestations of fracturing that are observed in some of the rocks in the area may be related to Late thermo-tectonometamorphic deformational events, i.e. the Pan-African Orogeny and secondary deformation events [4, 43].

Since the Kushaka schist belt exhibits similar geologic setting and ore genesis with the Maru schist belt, the mineral paragenesis of the gold-bearing quartz veins outlined by Oke et al. [40] could provide a better insight to the hydrothermal alteration processes that precipitate gold minerals in the study area. This encompasses the formation of protolith by magmatic activity that was subsequently deformed and reworked by episodic tectonometamorphic deformation events. The gold thiosulfate complexes were promoted through formation mechanisms such as pyritization, devolatilization, wall-rock sulfidation, replacement of ferric ions by auric ions, adsorption, reduction, phase immiscibility and precipitation [38, 44-47]. This was later succeeded by the active passage of hot hydrothermal auriferous fluid constituting quartz, gold, and magnetite. As a result of isochemical interactions between the hydrothermal mineralizing fluids and the protolith, hematite replaced magnetite. The precipitation of gold thiosulphate complexes at the higher crustal level under favourable pressure-temperature conditions was promoted by hydrothermal fluids. Consequently, there was an emergence of secondary minerals such as amorphous silica, sericite, epidote, and chlorite forming haloes round the rim of gold-bearing quartz veins, hosted in greenschist, 

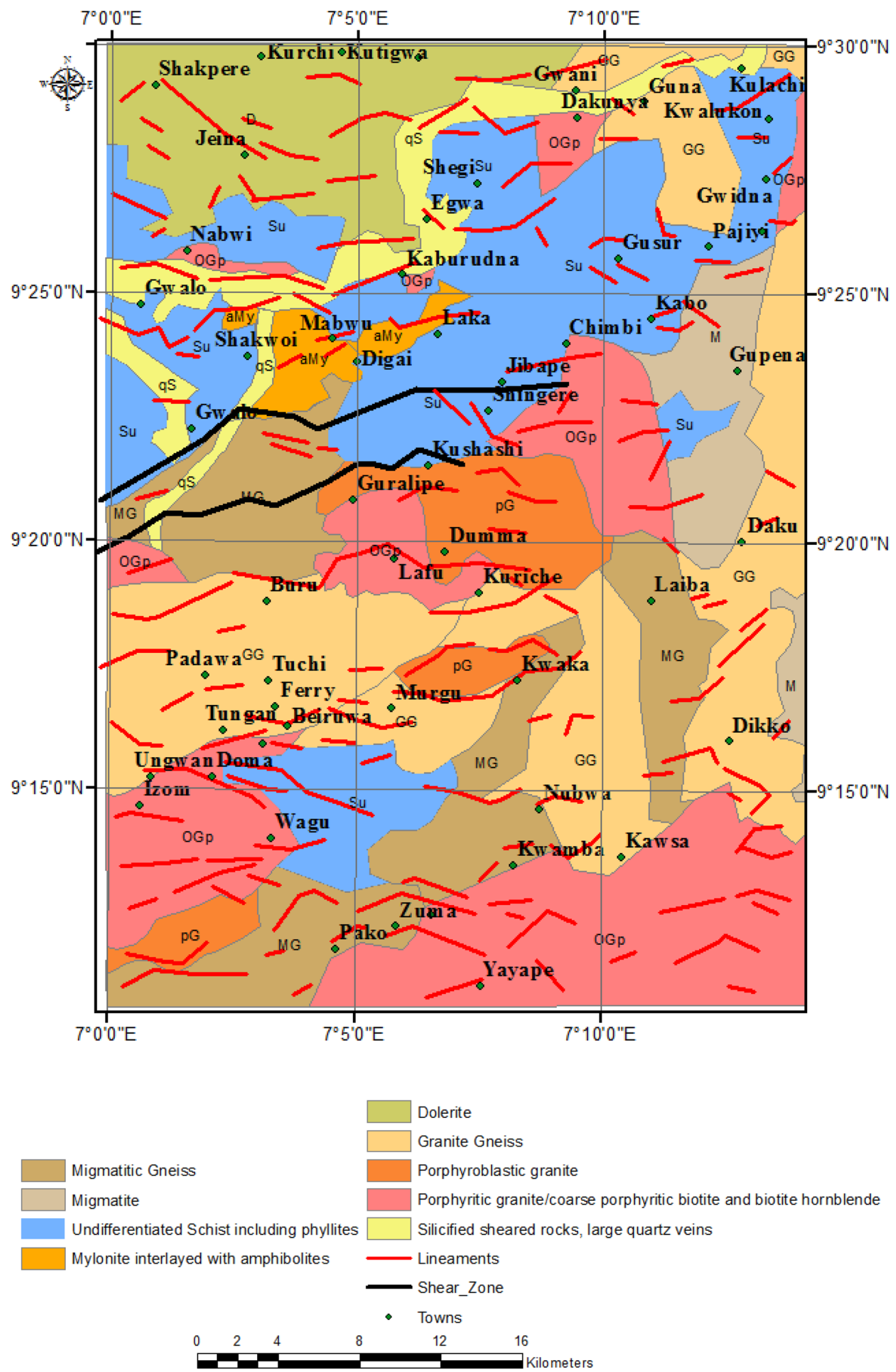

Fig. 3 Geological map of the study area (modified after NGSA [59]) 
phyllites and gneisses in the area. Hence, the main alteration types that are associated with gold mineralization in the Kushaka schist belt are: potassic, phyllic, prophyllitic alteration, and silicification [30, 40,47].

\subsection{Formation mechanisms of hydrothermal alteration subsystem}

The mineral systems approach [48-54] can be employed to better understand hydrothermal alteration subsystem that is related to orogenic gold mineralization in the study area. Under dehydration and devolatilization metamorphic conditions, the presence of iron-rich mineral assemblage (pyrite, chalcopyrite, covellite, chalcocite, molybdenite, galena) and metapelitic minerals (chlorite, sericite, quartz, epidote, albite and calcite) present in phyllites and greenschists in the study area promoted the formation of metamorphic fluids and gold ligand (HS') $[15,30,38,44,45,47$, 55-58]. Due to melt/magma mixing, crystal segregation, adsorption, phase immiscibility and sulfur globulization during granitoid emplacement, the mixing of the oxidized magmatic fluids with the metamorphic fluids and gold ligands $\left(\mathrm{HS}^{-}\right)$resulted to an increment in oxygen fugacity, thereby promoting the precipitation of orogenic gold minerals $[15,30,40,47,52,53]$.

Geologic structures such as faults, shear zones, fractures, and lithological contacts (where rheological contrast is significant) constitute migration pathways for the deepseated hydrothermal fluids comprising of gold thiosulfate complex $\left[\mathrm{Au}\left(\mathrm{S}_{2} \mathrm{O}_{3}\right)_{2}\right]^{3-}$ to precipitate and localize gold minerals at higher crustal $[30,53]$. Under suitable temperature and pressure conditions, the interactions between metamorphic fluid (composing of auriferous fluid, gold ligands, water, silica, sulphide and chlorine compounds, carbonates, and ions of potassium, sodium, calcium, iron and magnesium) and tectonically deformed rocks led to the emergence of hydrothermal alteration targeting element. Hydrothermal alteration is one of the constituent processes of a syn-mineralization subsystem, i.e. a chemical scrubber that promotes the precipitation of potassium, sulfur, and gold minerals [30,53]. Consequently, potassic $\left(\mathrm{KAl}_{3} \mathrm{Si}_{3} \mathrm{O}_{10}(\mathrm{OH})_{2}\right)$, phyllic $\left(\mathrm{KAl}_{2}\left(\mathrm{AISi}_{3} \mathrm{O}_{10}\right)(\mathrm{OH})_{2}\right)$ and prophylitic $\left(\mathrm{Al}_{2} \mathrm{Si}_{4} \mathrm{O}_{10}(\mathrm{OH})_{2}\right)$ alteration haloes are formed with orogenic gold mineralization [14, 30].

\section{Materials and methods}

A digital format of aeromagnetic data (Abuja Sheet), acquired using 3x Scintrex CS3 Cesium Vapour magnetometer mounted on 7 Cessna Caravan fixed-wing aircrafts and Flux-Adjusting Surface Data Assimilation System (FASDAS) for data acquisition and magnetic counter, was gotten from the Nigerian Geological Survey Agency (NGSA), Abuja. The total magnetic intensity (TMI) data, which was financed by the Federal Ministry of Mines and Steel Development, was acquired between 7 December, 2006, and 31 May, 2007, and processed on behalf of NGSA by Fugro Airborne Surveys in 2009. The magnetic data was subjected to standard processing procedures such as diurnal correction, de-culturing, magnetic compensation, de-spiking, directional filtering, micro-leveling and geomagnetic correction [59]. The TMI data obtained from NGSA has been stripped off $32,000 \mathrm{nT}$, being the International Geomagnetic Reference Field (IGRF) value over the survey area, during the compilation of the dataset [59].

Likewise, a digital format of high resolution airborne radiometric data (Abuja sheet), acquired using 512-channels gamma-ray spectrometers ( $\mathrm{Nal}$ " $\mathrm{Tl}$ " crystals) mounted on fixed-wing aircraft, was obtained from the Nigerian Geological Survey Agency (NGSA), Abuja. Nal "Tl" crystal size of 2 " $\times 2$ " was used for the airborne gamma-ray spectrometry survey [59]. The radiometric data was acquired and processed into grids ( $50 \mathrm{~m}$ cell size) by Fugro Airborne surveys between 2002 and 2009. The total magnetic field and radiometric data were taken at recording intervals of about $0.1 \mathrm{~s}$ with sensor mean terrain clearance of $80 \mathrm{~m}$ above the ground level. The flight line direction was NW-SE $\left(135^{\circ}\right)$, and the control line was in NE-SW direction $\left(45^{\circ}\right)$. The flight line spacing of $500 \mathrm{~m}$ and control line spacing of $2000 \mathrm{~m}$ were employed [59]. The map projection used in this study is the Universal Transverse Mercator (UTM) zone $32 \mathrm{~N}$, by assuming the approximation of Clarke 1880 (Modified) as the reference spheroid ellipsoid and the World Geodetic System 1984 (WGS'84) as Datum.

In order to achieve seamless data and minimize aliased artefacts in the data [60], the TMI data was gridded with grid mesh size of $50 \mathrm{~m} \times 50 \mathrm{~m}$ by adopting minimum curvature gridding method $[61,62]$. The aeromagnetic data was upward continued to a plane height of $200 \mathrm{~m}$ in order to remove high-frequency anomalies (which are usually cultural) that stem from sources on or near the ground surface over the study area and amplify the deep-seated geologic structures prior further processing [22]. Due to the proximity of the study area to the equator (i.e. magnetic inclination and magnetic declination of $-5.40^{\circ}$ and $-1.88^{\circ}$, respectively), reduction to equator transformation was performed on the TMI data. This transformation was performed with the intention of removing asymmetry that is usually associated with magnetic anomalies at low latitudes, and to reposition the magnetic anomalies over the magnetic sources as those at the magnetic equator [63-65].

Regional-residual separation was performed on the denoised and RTE transformed data by using upward continuation filter that is available on Geosoft Oasis Montaj ${ }^{\mathrm{TM}}$ 
version 6.4.2 (HJ) software. In this study, the reduction-tothe-pole (RTP) was not performed on the data because, the study area is at a low magnetic latitude $\left(<15^{\circ}\right)$ where the RTP transformation is especially unstable, and dominated by declination line-parallel artefacts and phase shift [64, 66-68]. After carrying out upward continuation to an optimum surface height of $500 \mathrm{~m}$ by ensuring that there are no vestiges of residual field, i.e. short-wavelength anomalies in the data, the resulting regional magnetic field of the study area emphasizes the deep-seated, long-wavelength magnetic anomalies. Residualization, as the name implies, is the estimation of expected residual magnetic fields by removing the estimated regional field values over an area or profile from the observed total magnetic field values [22]. The residualization of the TMI data in this study assists in accentuating the shallower magnetic effects at the expense of deeper magnetic sources, which is of prime interest in mineral exploration. As such, the residual magnetic intensity data contains principally information about the crustal magnetic field effects of the study area, which is of fundamental interest in this study.

The enhancement techniques applied to the residual magnetic intensity data for structural mapping of the study area include analytic signal, total horizontal derivative, tilt derivative of total horizontal derivative and 3-D standard Euler deconvolution. Lineaments were extracted from the results of enhancement filters employed in this study by considering results that exhibit excellent agreement, most especially with the 3-D standard Euler deconvolution and the tilt of total horizontal derivative results. Likewise, PCl Geomatica software, which relies on line method, was employed for lineament extraction from Shuttle Radar Topography Mission (https://earthexplorer. usgs). The extracted lineaments from the Shuttle Radar Topography Mission (SRTM) were employed to cross-check the lineaments from the aeromagnetic analysis in order to produce a reliable structural framework map for the study area.

\subsection{Edge detection techniques}

\subsubsection{Analytic signal amplitude (ASA)}

Analytic signal amplitude can be defined as the rootsquare of the squared sum of the vertical and orthogonal derivatives of the total magnetic field.

$A(x, y)=\sqrt{\left(\left(\frac{\partial T}{\partial x}\right)^{2}+\left(\frac{\partial T}{\partial y}\right)^{2}+\left(\frac{\partial T}{\partial z}\right)^{2}\right)}$

where $A(x, y)$ is the amplitude of the analytic signal at $(x, y)$ position, $T$ is the observed magnetic anomaly at $(x, y)$, $\partial T / \partial z$ is the vertical derivative of the total magnetic field and $\partial T / \partial x, \partial T / \partial y$ are the orthogonal derivatives of the total magnetic field in the $x$ - and $y$-planes, respectively.

ASA is independent of the ambient induced magnetic field and direction of source magnetization vector. It peaks over magnetic sources, where there is significant magnetization contrast, at the low amgnetic latitudes as if reduction-to-the pole (RTP) transformation was performed on the TMI data at higher latitudes $\left(>15^{\circ}\right)$.

It is worth noting that, analytic signal technique applied in this study has the ability to define source positions irrespective of Koenigsberger ratio and strike of the magnetic sources, magnetic declination and inclination of the survey area. Thus, it is essentially useful in delineating magnetic sources like geologic structures most especially the shallower magnetic bodies in the subsurface [69].

\subsubsection{Total horizontal derivative (THD)}

The total horizontal derivative (THD) technique is the fastest and more efficient approach in estimating contact locations of causative bodies at crustal depths. This efficiency is as a result of its ability to give a peak anomaly over the magnetic contacts [69-71]. The technique is known for its low sensitivity to noise in the magnetic data because it essentially requires the computation of the first-order horizontal derivatives of the magnetic field in the $x$ - and $y$-directions. It is expressed as in Eq. 2:

$\operatorname{THD}(x, y)=\sqrt{\left(\frac{\partial T}{\partial x}\right)^{2}+\left(\frac{\partial T}{\partial y}\right)^{2}}$

where $T$ is the magnetic field intensity, $\partial T / \partial x$ and $\partial T / \partial y$ are the orthogonal derivatives of the magnetic field intensity.

This function assumes that the regional (i.e. nominal) field and source of magnetizations are vertical. Likewise, the magnetic contacts are assumed to be vertical and isolated, and the magnetic sources are substantially thick. The reduction-to-pole (RTP) transformation being the precursor for THD operations is generally unstable and cannot be easily derived at the magnetic equatorial locations where inclination is less than $15^{\circ}$ (such as the case of the study area) [65]. Hence, the THD technique was performed on the RMA that have been subjected to RTE transformation by assuming that, the regional and induced magnetization of the magnetic sources are horizontal.

\subsubsection{Tilt derivative of total horizontal derivative (TDR THD)}

The tilt derivative of the total horizontal derivative (TDR THD) is obtained by taking the ratio of arctangent of the vertical derivative of the total horizontal derivative and 
the modulus of the total horizontal derivative in the $x$ - and $y$-planes. It is expressed as in Eq. 3 [71]:

$T D R \_T H D=\tan ^{-1}\left(\frac{\frac{\partial T H D}{\partial z}}{\sqrt{\left(\frac{\partial T H D}{\partial x}\right)^{2}+\left(\frac{\partial T H D}{\partial y}\right)^{2}}}\right)$

Owing to the properties of the arctangent function, the TDR_THD values range between $-\pi / 2$ and $+\pi / 2$ radians. The focal characteristics of the TDR_THD are to provide peak amplitudes over the edges of magnetic sources and then normalize signals from both shallow and deep sources.

The approach of Ferreira et al. [71] was employed in this study by using the already obtained total horizontal derivative (THD) grid as the input grid for tilt-angle derivative (TDR) enhancement filter available on MAGMAP program of the Geosoft's Oasis Montaj software. Thus, the tilt of total horizontal derivative proposed by Ferreira et al. [71] combines the advantages of tilt-angle and total horizontal derivatives for a better imaging of magnetic edges. Therefore, TDR_THD filter can provide a useful tool for structural mapping.

\subsubsection{Source edge detection (SED)}

The source edge detection (SED) filter works by locating peaks from TMI data through analyzing the orthogonal derivatives of the TMI data. Most often, the peaks from the SED filter correspond to the edges of magnetic sources that can assist in delineating geological contacts within an investigated area. SED does this function by estimating the location of sudden lateral magnetization contrast with the neighbouring rocks within the crustal levels [72].

The locations and gradient directions of the magnetic field anomalies are usually displayed as feathery-like black symbol. The source edge detection was performed on Oasis Montaj software by inputting THD and RTE residual magnetic anomaly (RMA) grids into sed.omn available on Geosoft eXecutable program of Oasis Montaj software.

\subsubsection{3-D Euler deconvolution (ED) technique}

The 3-D standard Euler deconvolution was used in this study for the purpose of lineament trend analysis and depth estimation [73, 74]. The 3-D standard Euler deconvolution is efficient for boundary finding and depth estimation, as it is capable of estimating source location and depth of the magnetic anomalies in any geologic setting $[73,74]$.

Euler deconvolution works on the potential data directly by generating mathematical solutions, yet without a recourse to any geological constraints. Generally, ED is used in TMI data interpretation because it only requires a minute or no involvement of prior knowledge about the magnetic source geometry within a survey area. More importantly, it requires no information about the magnetization vector. The 3-D standard Euler deconvolution technique utilized in this study is based on solving Euler's homogeneity equation (Eq. 4) [74]:

$\left(x-x_{0}\right) \frac{\partial T}{\partial x}+\left(y-y_{0}\right) \frac{\partial T}{\partial y}+\left(z-z_{0}\right) \frac{\partial T}{\partial z}=\eta(\beta-T)$

where $\beta$ is the nominal value of the magnetic field and $x_{0}, y_{0}, z_{0}$ define the source position, which gives the total magnetic intensity field $T$ measured at $(x, y, z) ; \eta$, being the structural index, is the most important parameter. The geometry and depth of the magnetic field sources can be estimated by basically varying the structural index, $\eta$. Erroneous choice of $\eta$ can cause a diffuse and spurious solution of magnetic source locations and ultimately results to a serious bias in the depth estimation of magnetic sources [74]. A suitable choice of structural index, $\eta$, is pivotal to unbiased lineament trend analysis, depth estimation and source geometry determination.

Geosoft's Oasis Montaj ${ }^{\mathrm{TM}}$ allows the sampling window size to be varied from 3 to 20 , depending on the wavelength and size of the sampled anomalies. The best sampling window size gotten for this study is 15 . Since structural framework is not strictly homogenous, the right structural index with the best clustering solution is assumed to represent the geologic model of an area [74]. Structural indices varying from 0 to 3 were experimented, but structural index of 1 gave good clustering solutions in this study. Euler solution of $\eta=1$, which matches well with the dyke/fault model was employed to constrain other derivative results for faults mapping in the investigated area particularly, the tilt of total horizontal derivative result.

\subsection{Hydrothermal alteration indicators}

Probing for hydrothermal alteration zones indicates exploring areas with fractures within the crustal levels that can provide conduits for hydrothermal fluids (temperatures between 50 and $500{ }^{\circ} \mathrm{C}$ ) to interact with the tectonically deformed crustal rocks [7]. It has been established that there is a proven relationship between potassium enrichment, and hydrothermal and orogenic gold mineralizing processes [7, $11,21]$. Due to this foregoing reason, regions of potassium enrichment that are accentuated from the radiometric data were used to demarcate hydrothermally (such as potassic, phyllic and prophylitic) altered areas. A good point to note, thorium is less geochemically mobile than potassium and 
uranium [75]. In this study, thorium (eTh) was used as a lithological background control to define ideal $\mathrm{eU}$ and $\mathrm{K}$ values. Thus, the normalization of radiometric data by eTh values is necessary to overcome the effects of the environment, leaching, weathering and lithology on $\mathrm{K}$ and eU concentrations $[16,76]$.

In order to solve the problem of separating anomalous $\mathrm{K}$ values (potassium enrichment) related to hydrothermal alteration from those related to lithology such as leaching, normal mineralogical composition and bio-chemical weathering effects, ratio of equivalent thorium concentration to the potassium counts, i.e. eTh $/ K, F$-parameter (i.e. ratio of the product of potassium $(K)$ counts and equivalent uranium (eU) concentration to the equivalent of thorium (eTh) concentration) proposed by Efmov [37] and the deviation from the ideal $K$ values (Kd) proposed by Saunders [16], were utilized in mapping hydrothermal alteration haloes that are related to orogenic gold mineralization in the study area.

Galbraith and Saunders [35] showed that thorium impoverishment mostly occurs with potassium enrichment during hydrothermal alteration processes. This hydrothermal alteration syn-mineralization subsystem is normally associated with various types of volcanic-associated massive-sulfide (VMS) base-metal and gold deposits [7, 20, 34]. As such, K/ eTh ratio provides an excellent discrimination of hydrothermal alteration haloes from ordinary lithological differentiation effects. The $F$ parameter proposed by Efmov [37] was also applied because it includes two significant relationships, the richness of $\mathrm{K}$ related to $\mathrm{eTh} / \mathrm{eU}$ ratio and the richness of $\mathrm{eU}$ related to the eTh/K ratio (Eq. 6) [21]:

$F=\frac{\mathrm{K} * \mathrm{eU}}{\mathrm{eTh}}=\frac{\mathrm{K}}{\frac{\mathrm{eTh}}{\mathrm{eU}}}=\frac{\mathrm{eU}}{\frac{\mathrm{eTh}}{\mathrm{K}}}$

Based on the method proposed by Saunders et al. [16] and Pires [76], the nominal $K$ value $\left(\mathrm{K}_{\mathrm{n}}\right)$ in relation to the equivalent thorium (eTh) concentration was extracted from Eq. 6 [21].

$\mathrm{K}_{\mathrm{n}}=\left(\frac{\mathrm{K} \text { map }_{\text {average }}}{\text { Th map }_{\text {average }}}\right) *$ Th map

The values for $\mathrm{K}$ map average and eTh map average $\mathrm{used}$ for this study as obtained from the statistics of the $K$ and eTh grids were $1.81 \%$ and 12.53 ppm, respectively. Deviation from the nominal $K$ values $(\mathrm{Kd})$ was considered to represent potassium enrichment values due to hydrothermal alteration processes as obtained by Eq. 7 [21]:

$K_{d}=\frac{K-K_{n}}{K_{n}}$

The hydrothermal alteration map of the study area was developed from eTh/K (inverted form of K/eTh), $F$
Table 1 Selected mines/mining pits in the study area

\begin{tabular}{lllll}
\hline $\begin{array}{l}\text { Mining } \\
\text { pits/ } \\
\text { mine }\end{array}$ & Location & $\begin{array}{l}\text { Eastings }(\mathrm{mE}) \\
\text { UTM zone } \\
32 \mathrm{~N}\end{array}$ & $\begin{array}{l}\text { Northings } \\
(\mathrm{mN})\end{array}$ & Mineral mined \\
\hline 1 & Nabwi & $285,745.108$ & $1,042,137.238$ & Gold \\
2 & Gwalo & $284,159.1509$ & $1,036,528.91$ & Gold \\
3 & Jipape & $294,254.5249$ & $1,038,986.529$ & Gold \\
4 & Jipape & $294,557.006$ & $1,038,721.919$ & Gold \\
5 & Jipape & $295,255.7589$ & $1,038,711.072$ & Gold \\
6 & Shingere & $295,291.0394$ & $1,038,252.463$ & Gold \\
7 & Buru & $286,224.6859$ & $1,030,456.082$ & Gold \\
8 & Izom & $281,179.9878$ & $1,023,294.749$ & Gold \\
9 & Kwaka & $295,361.5872$ & $1,027,034.15$ & Gold \\
\hline
\end{tabular}

Table 2 Geochemical sampling points in the study area

\begin{tabular}{lllc}
\hline $\begin{array}{l}\text { Geochemical } \\
\text { sample point }\end{array}$ & $\begin{array}{l}\text { Easting }(\mathrm{mE}) \\
\text { UTM zone 32 N }\end{array}$ & Northing $(\mathrm{mN})$ & $\begin{array}{l}\text { Grade of } \\
\text { Gold }(\mathrm{ppm})\end{array}$ \\
\hline Jibape & $294,254.5249$ & $1,038,986.529$ & 6 \\
Jibape & $294,557.006$ & $1,038,721.919$ & 4 \\
Jibape & $295,255.7589$ & $1,038,711.072$ & 10 \\
Jibape & $295,291.0394$ & $1,038,252.463$ & 6 \\
\hline
\end{tabular}

parameter and Kd results, and field observations in the area. The spatial locations of existing mine sites (Kwaka, Shingere, Shakwoi, Buru and Gurara) and the accessible mining pits dug by artisanal miners to exploit gold deposits in the area as well as gold grade occurrence map retrieved from https://www.winockmining.com/gurar a-gold-project/ on December 19, 2018, were utilized for the purpose of validating mineralization that is extracted from the geophysical analyses (Tables 1, 2). The delineated structures and hydrothermal alteration zones were correlated with the mineral occurrence locations and field observations in the area to establish the relationship between the geologic structures, hydrothermal alteration and orogenic gold mineralization.

\section{Results and discussion}

\subsection{Magnetic interpretation}

\subsubsection{Residual magnetic anomaly (RMA)}

The magnetic intensity of the RMA map ranges between -70.13 and $69.94 \mathrm{nT}$ (Fig. 4). The heterogenous magnetic expressions on this map reflect a high level of inhomogeneity and geological complexity in the study area. The variations in the magnetic intensity values of the area 


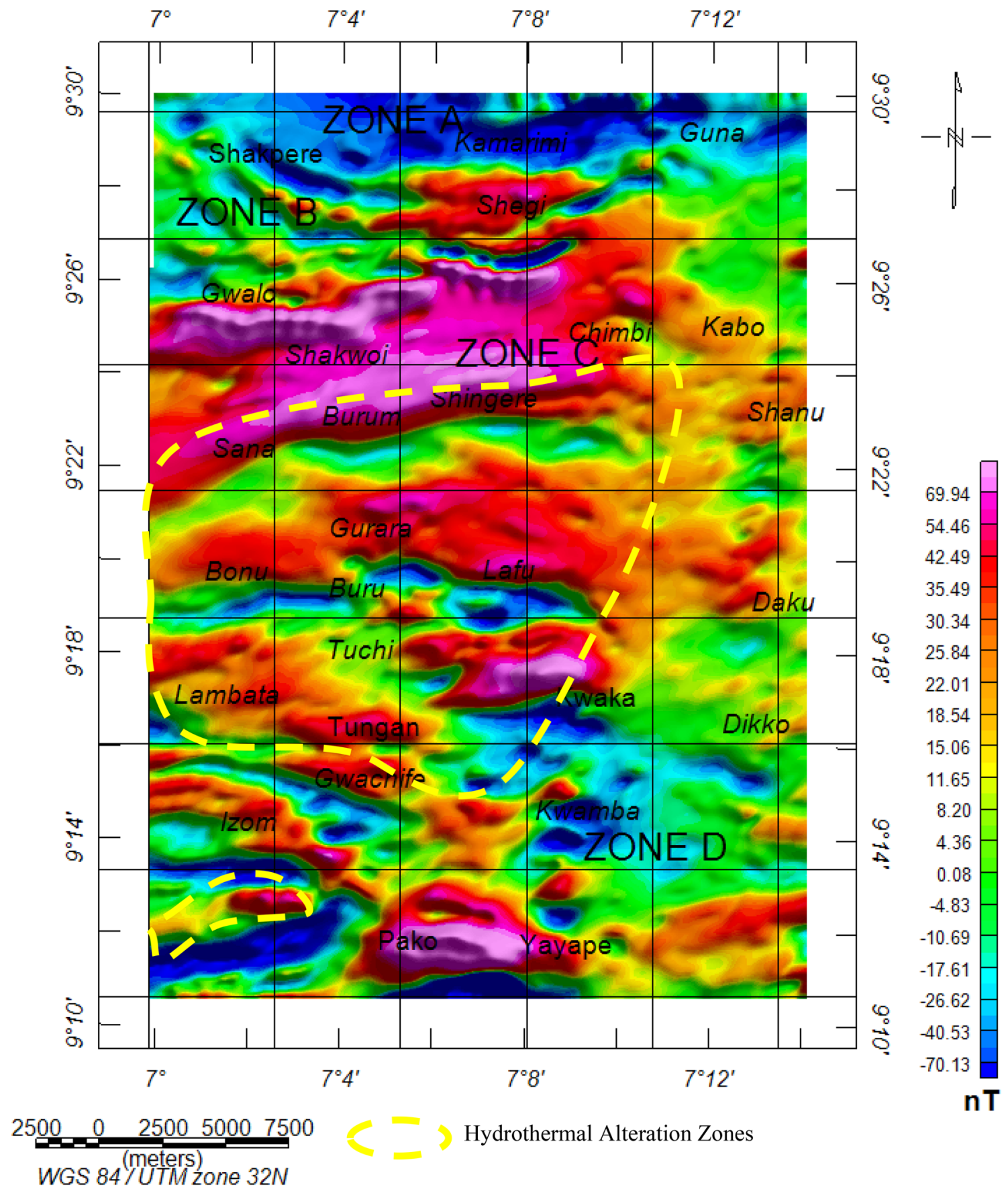

Fig. 4 Residual magnetic anomaly map of the study area

could probably stem from the complexity in the geologic setting in terms of different rock type distribution, tectonic history, regime of metamorphism, history of magmatic activity, hydrothermal alteration history and associated mineralization. High (positive magnetic intensity) and low (negative magnetic intensity) amplitude magnetic anomalies in low magnetic latitude areas as in this study area (Fig. 4) correspond to magnetic effects of subsurface rocks and geologic materials, having low and high magnetic susceptibilities, respectively $[65,77]$. Hence, negative magnetic intensity values (trough) are expected on magnetic anomalous body containing ferromagnesian minerals. The magnetic anomaly distribution on the map could assist to distinctly zone the study area into four, denoted as zone A, $B, C$ and $D$. The identified zones are based on the magnetic intensity values and magnetic patterns.

On the RMA map, zone A around Kamarimi and Guna is characteristically low with magnetic intensity values 
that range between -70.13 and $-10.69 \mathrm{nT}$ (Fig. 4). This zone dominates the extreme northern part of the study area. A careful examination of the RMA map with the local geology of the study area shows that, dolerite rock, a mafic rock that contains ferromagnesian minerals in form of olivine, plagioclase feldspar, pyroxene and magnetite in the area coincides with the negative magnetic intensity (i.e. possesses high magnetic susceptibility values) response. At this zone, a prominently positive magnetic intensity values that coincide with the undifferentiated schist are observed at Shegi (Figs. 3, 4). Phyllites and silicified, sheared quartz veins are predominant at Shegi and in some part of Guna; hence, the positive magnetic intensities on the magnetic map corroborate the local geology of the study area. The silicified, sheared quartz veins that run from Guna to Lambata provide hosting for the gold deposits as some of the mines are located along the quartz vein intrusion in the area (Fig. 3).

Magnetic zone $B$ exhibits relatively low magnetic intensity values that range between -4.83 and $15.06 \mathrm{nT}$. Evidences of brittle-ductile deformation around Shakpere within zone $B$ are well defined on the RMA map showing characteristic curved and concordant magnetic patterns (Fig. 4). These expressions of brittle-ductile deformation on the RMA map trend approximately NW-SE with minor ENE-WSW magnetic trend. As a result of several orogenic events in the area, dolerite dyke swarms and surficial manifestations of faulting and reworking on the dolerite rock are predominant at this zone B (Fig. 4).

Zone $C$ reveals relatively high magnetic intensity values ranging from 8.20 to 69.94 nT. Peak magnetic anomalies with brittle-ductile magnetic patterns, that trend in the ENE-WSW direction, are observed around Shakwoi, Burum, Shingere, Gurara and Sana in the northcentral part of the study area (Fig. 4). This weakly magnetic intensity (i.e. high positive magnetic intensity values, having low magnetic susceptibility) signature observed at zone $C$ is related to shearing and severe fracturing at the contact zone (where rheological contrast is significant) between the schist and granite bodies. At shear and fracture zones, introduction of oxidizing hydrothermal fluids through the tectonically deformed and permeable rocks may result to demagnetization of magnetite to hematite, and this may locally reduce the magnetite content of rocks, as observed in zone $C$ of the study area $[11,78]$. Thus, two fractured/ shear zones are suspected at this zone $C$, where major lithological contact between granite and schist bodies exists (Figs. 3 , 4). These shear zones run approximately $16 \mathrm{~km}$ in the area and many gold mines are found to be closely situated along these major geologic contacts. This is a strong indication that the orogenic gold mineralization in the area is shear-hosted.
Zone $\mathrm{D}$ at the southeastern part of the area displays low magnetic intensity values that range between -70.13 and $-17.61 \mathrm{nT}$. It is worth noting that the most prominent magnetic anomalies at zone D trend ENE-WSW and some others are trending in the NW-SE direction (Fig. 4). These magnetic patterns reflect the imprints of Pan-African and Kibaran orogeny that have taken place in the study area. Encouragingly, the evidences of polycyclic deformation events that manifested on the magnetic map are seen on migmatite gneiss and granite gneiss rocks in the area (Figs. 3, 4).

\subsubsection{Analytic signal map (AS)}

Analytic signal is a veritable tool for locating the edge of magnetized bodies, especially in areas of low magnetic latitudes like the study area. The analytic signal peaks and centers over magnetic source(s), among others, include lithological contacts, faults, fractures, shear zones and intrusives. The analytic signal map of Gurara area has amplitudes that range between 0.087 and $0.1904 \mathrm{nT} / \mathrm{m}$ (Fig. 5). Truncated magnetic anomalies are observed around Gwalo, Shegi, Kamarimi and Guna in the northwestern part of the study area, showing amplitudes in the range of $0.0498-0.1904 \mathrm{nT} / \mathrm{m}$. These truncated magnetic anomalies could reflect the imprints of brittle-ductile deformation in the area and are seen to trend approximately in the ENE-SW and WNW-SE directions. It is worthy of note that, an elongated, weakly magnetized body that is presumably due to shearing is observed around Sana, Burum, Shingere and Chimbi in the northcentral part the study area. This expression of weak magnetization marks the boundary between the schist and granite bodies in the study area (Figs. 3, 5). The suspected shear zone may possibly provide a local structural control for gold mineralization within the study area.

Izom and Gwachife areas are marked by moderately high AS values that range between 0.0559 and $0.1127 \mathrm{nT} / \mathrm{m}$, where brittle deformations with NW-SE magnetic trend are observed. Highly pronounced AS anomaly with evidences of brittle-ductile deformation is observed around Pako, Yayape (Fig. 5). The high expression of AS anomalies can be attributed to the presence of faulted porphyritic granite/coarse porphyritic biotite and biotite hornblende rocks, containing high abundance of magnetite in the area. These magnetic anomalies correspond to geologic structures that can provide migration pathways for the plumbing of mineralizing fluids and localization of gold deposits in the area. Also, extremely low AS anomalies are well expressed at the eastern part of the study area. This form of magnetic signature, at the eastern portion of the study area, could be attributed to a widespread of felsic rock suites such as migmatite, migmatite gneiss and 


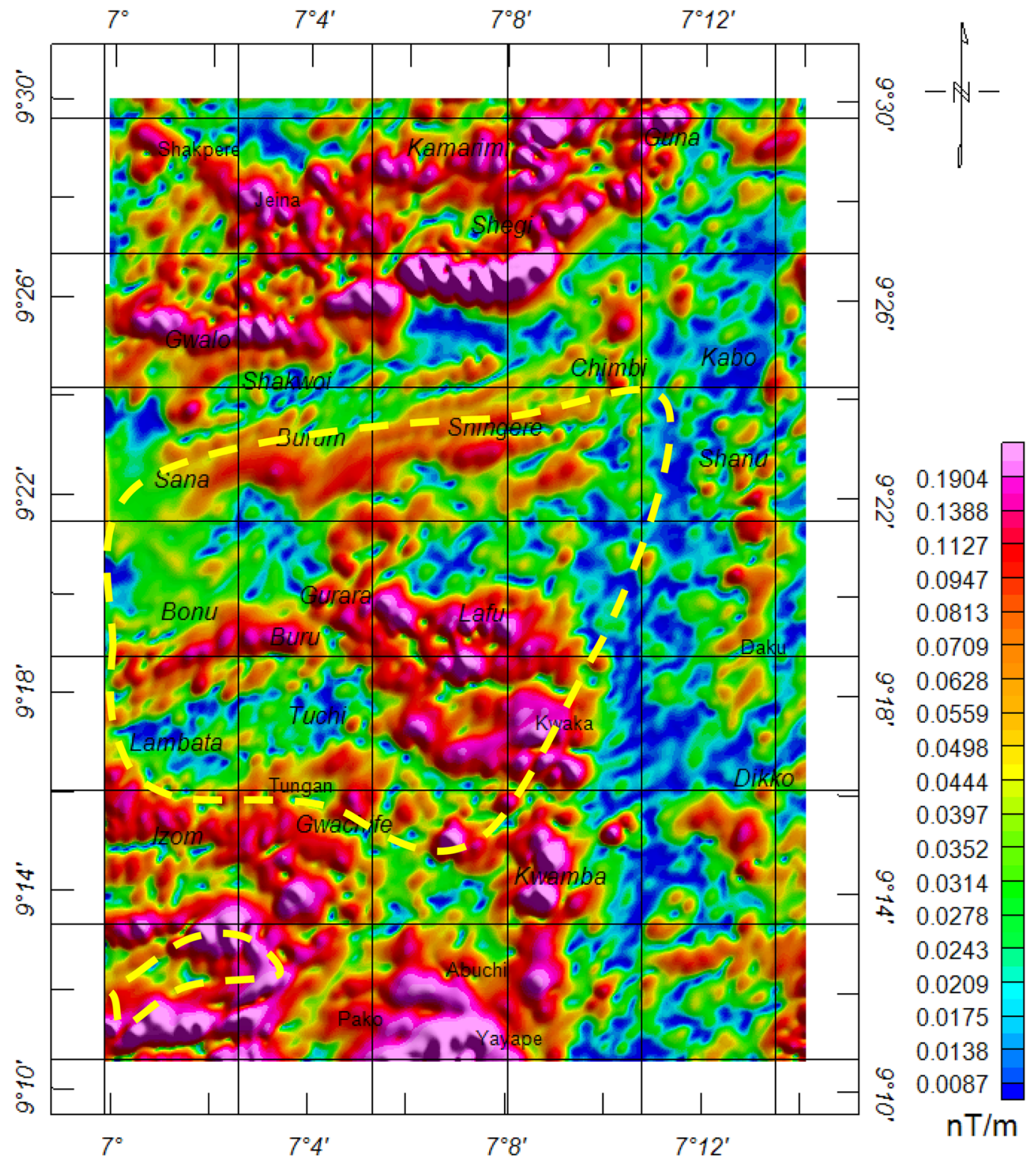

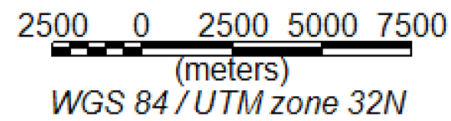

Fig. 5 Analytic signal map of the study area

granite gneiss, showing less evidence of faulting in the area.

\subsubsection{Total horizontal derivative (THD) map}

The map of the total horizontal derivative (THD) reflects structural complexity of the basement rock in the study area (Fig. 6). On the THD map, peak anomalies are often observed over geologic contact zones such as fracture, shear zones and faults $[22,77]$. The amplitudes of the total horizontal gradient range between 0.0038 and $0.1289 \mathrm{nT} / \mathrm{m}$. Based on these variations on the THD map, the Gurara area can be vividly demarcated into four major zones denoted as $A, B, C$ and $D$.

As a result of high magnetic susceptibility contrast between the adjacent magnetized blocks, zone A shows peaks of high gradient anomalies that correspond to geological contacts like lithological contacts and fractures. Several distinctive peaks that correspond to dyke

\section{SN Applied Sciences}




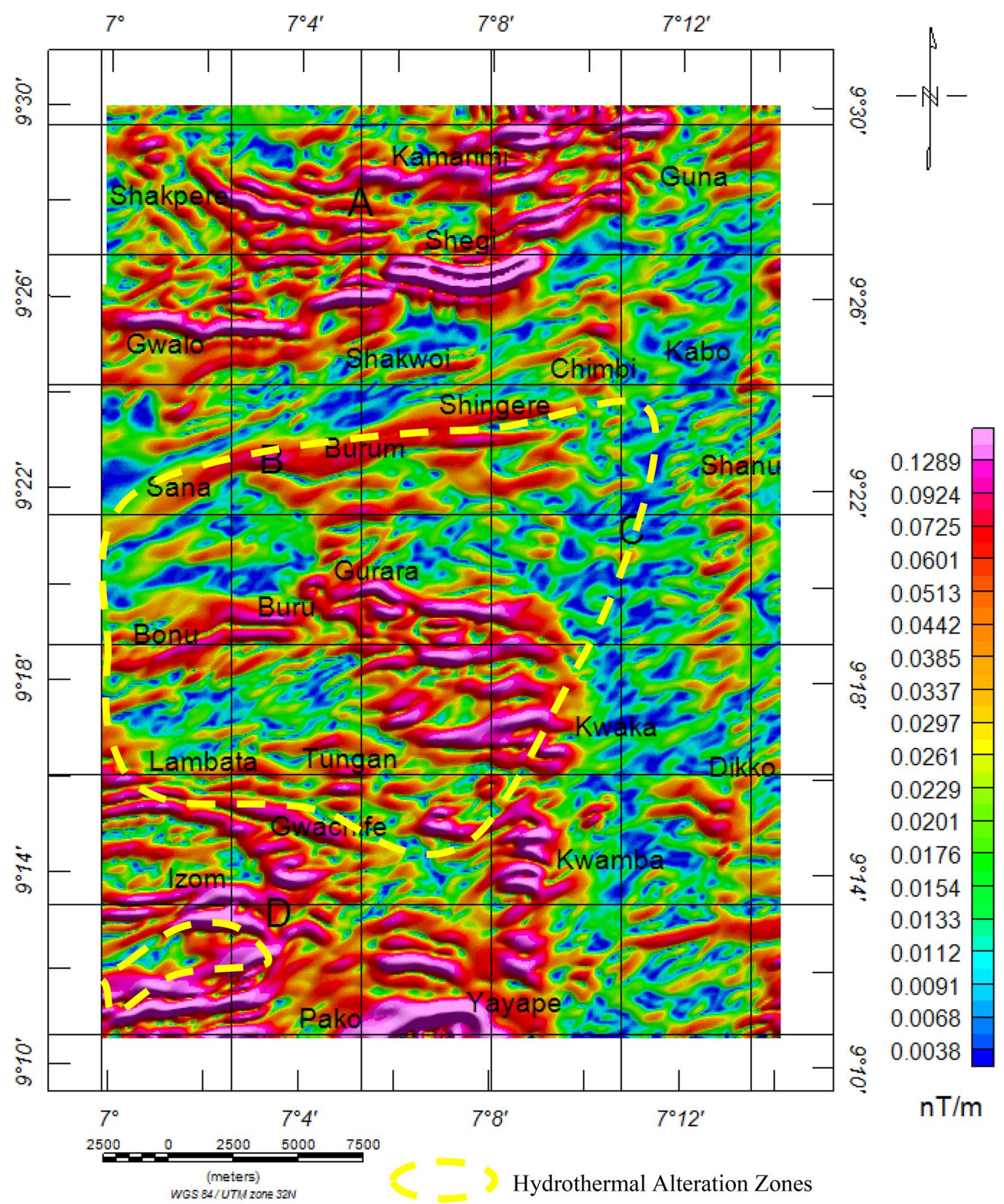

Fig. 6 Total horizontal derivative (THD) map of the study area

swarms are observed on the dolerite rock within this zone (Figs. 3, 6).

Zone $\mathrm{B}$ is marked by weakly magnetized bodies that trend ENE-WSW. The amplitudes of the THD in this zone vary between 0.0201 and $0.0725 \mathrm{nT} / \mathrm{m}$, which are typical of low magnetic susceptibility bodies (Fig. 6). The extremely low horizontal gradient values observed at this zone B could be attributed to demagnetization of magnetite to hematite. The expressions of demagnetization, more often than not, are associated with shearing and hydrothermal alteration processes. It is interesting to note that the evidence of shearing and hydrothermal alteration suspected around Sana, Burum, Shingere is better defined on the THD map. Also, evidences of hydrothermal alteration processes are well expressed around Bonu, Lambata, Tungan and Kwaka (Fig. 6). The suspected hydrothermal alteration 
haloes on the THD map correspond to areas where primary gold mineralization is found in the study area. The hydrothermal alteration haloes observed on the THD map coincide with rim-like haloes that form round some of the primary gold mineralization in the area. The primary gold mineralization was seen to be hosted by large silicified quartz veins that intruded different lithologies, most especially at the major fracture zone around Buru, Sana, Tungan, Gwachife and Gurara in southwestern part of the study area (Figs. 3, 6). The remarkable development of hydrothermal alteration haloes in form of sericitization, silicification, prophyllitization and potassic alterations that are observed on different lithologies, most especially on granite gneiss, stemmed from hydrothermal alteration processes on sericite-epidote-quartz mineral assemblage in the area. These manifestations are observed to principally trend in the ENE-WSW direction depicting that brittle-ductile deformation, hydrothermal alteration and primary gold mineralization mineral system can be traced to Pan-African orogeny in the area.

A careful examination of geological and THD maps of the study area reveals that the manifestations of low gradient signatures within zone $C$ coincide with areas where granite gneiss and migmatites show less traces of faulting (Figs. 3, 6). Zone D shows prominent expressions of peak anomalies which trend principally in the ENE-WSW direction. The expressions of ENE-WSW faulting that are observed in the Gurara area are peculiar to many schist belts in Nigeria (Fig. 6). The ENE-WSW faulting is considered as the regional structural control on the gold mineralization in the study area $[4,5,41,44]$.

\subsubsection{Source edge detection (SED) map}

SED map benefits principally from the total horizontal derivative (THD) in delineating abrupt lateral changes in magnetization. Thus, SED can assist in mapping geological features such as lithological contacts, faults, fractures and shear zone (region of intense deformation), among others. On the SED map, a major structure (i.e. the suspected shear zone) that trends in the ENE-WSW direction is well defined in areas around Sana, Burum and Shingere (Fig. 7). The accentuated geologic structures that trend in ENE-WSW and NW-SE directions on the THD map further reflect the effects of Pan-African thermotectonic events Ca $650 \mathrm{ma} \pm 150$ ma which have taken place in the Gurara area. Pan-African orogeny, which is characterized by the emplacement of granitoid bodies, could have supported granitic intrusion that are seen in the area (Figs. 2, 7). Therefore, granitoid intrusions, most especially granites and dolerite are likely to play heat engine and metal source roles in the deposition of gold in the Gurara area [30].

SN Applied Sciences

\subsubsection{Tilt derivative of total horizontal derivative (TDR THD) map}

Generally, TDR_THD map has a good correlation with local geology as in the case of this study area; thereby it serves as an effective tool for a reliable structural mapping [71]. Continuous, thin and curvilinear magnetic patterns that are characteristic of lithological contacts and major geological structures in the study area are better accentuated on the TDR_THD map (Fig. 9). Similarly, magnetic anomalies on the TDR_THD map trend principally in the ENE-WSW direction, thus reflecting the footprints of the Pan-African orogeny in the area.

However, few areas especially around Kamarimi, Shegi and Shakpere, showcase structural trend in the E-W and NW-SE directions, which could be from the relics of Liberian and Kibaran orogeny, respectively. It is worthy of note that, areas around Sana, Burum, Shingere, Gurara, Buru, Kwaka to mention but a few, have structural trend of ENE-WSW and these are locations where artisanal mining activities are currently ongoing as at the time of this study (Fig. 9). Thus, it can be deduced from this standpoint that ENE-WSW structural trend constitutes a first-order control on the orogenic gold mineralization in the Gurara area and possibly in other parts of the Kushaka schist belt of Nigeria.

\subsubsection{3-D standard Euler deconvolution map}

The determination of the geometry of magnetic anomalies from 3-D standard Euler deconvolution is a function of employing an appropriate structural index with good clustering solutions. However, the resolution and wavelength of magnetic anomalies are dependent on the window size $[74,79]$. The bead-like shape and different colourations that are usually observed on Euler deconvolution maps are the reflections of the spatial locations and depth levels of the delineated magnetic sources.

In this study, the best clustering for Euler solutions was achieved with $\mathrm{SI}=1.0$, which is diagnostic of thin dyke/ fault model (denoted as $\mathrm{D}$ ) with large depth/throw ratio (Fig. 8). It is evident that the clustered Euler solutions of $\mathrm{SI}=1$ show an excellent correlation with local geology of the study area and other data enhancement techniques results in this study, most especially with TDR_THD (Fig. 9). Also, the window size of $1500 \mathrm{~m}$ by $1500 \mathrm{~m}$ used in this map depicts that the wavelength of the delineated fault/dyke tends to unity. This window size was adopted because it reliably captures the entire size of the magnetic anomalies being analysed, with the exclusion of multiple anomalies (which could be related to noise in the TMI data). Therefore, a deep-seated, brittle-ductile shear/ fracture zone that has been earlier suspected in this study 


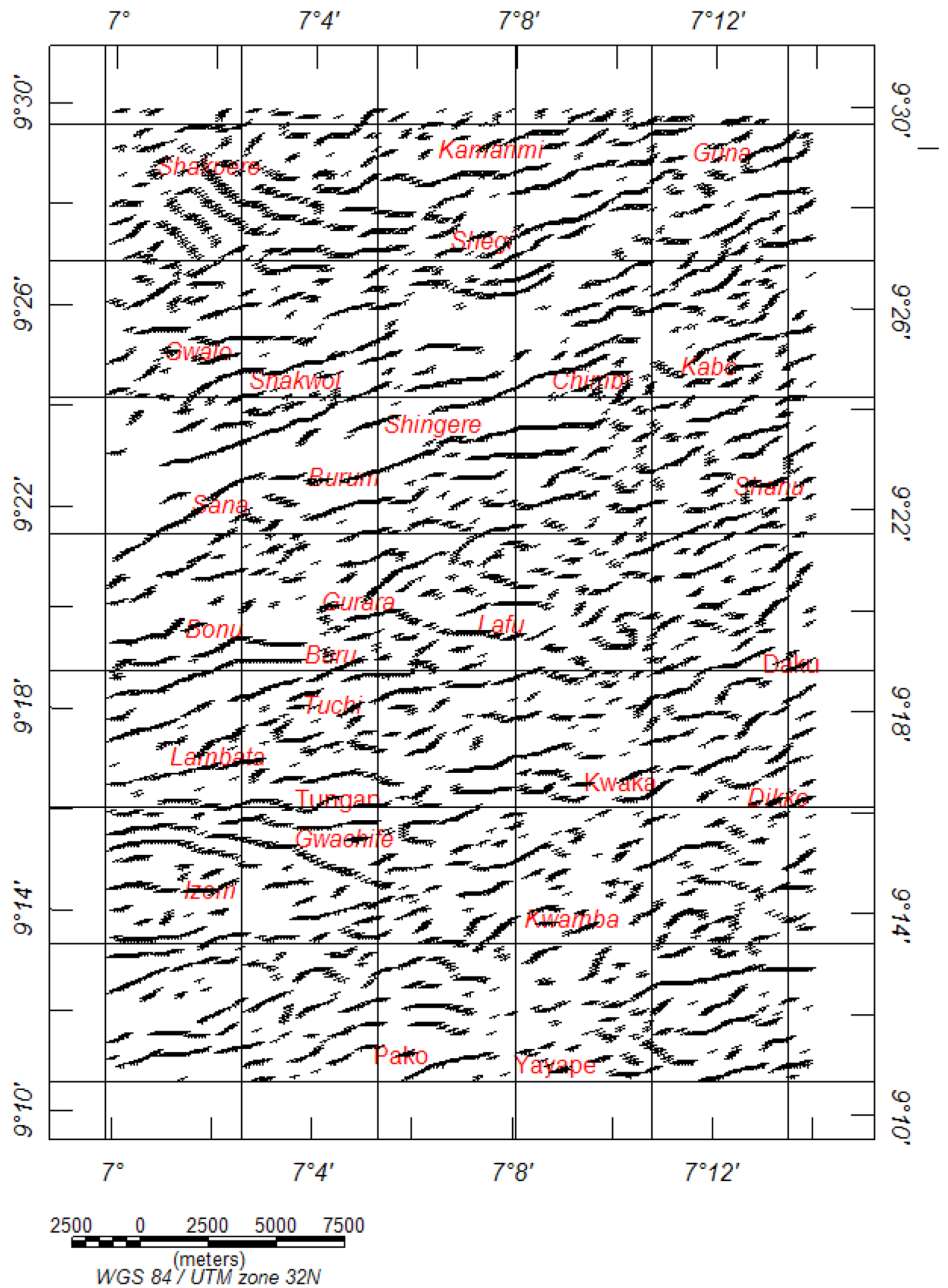

Fig. 7 Source edge detection (SED) map of the study area 


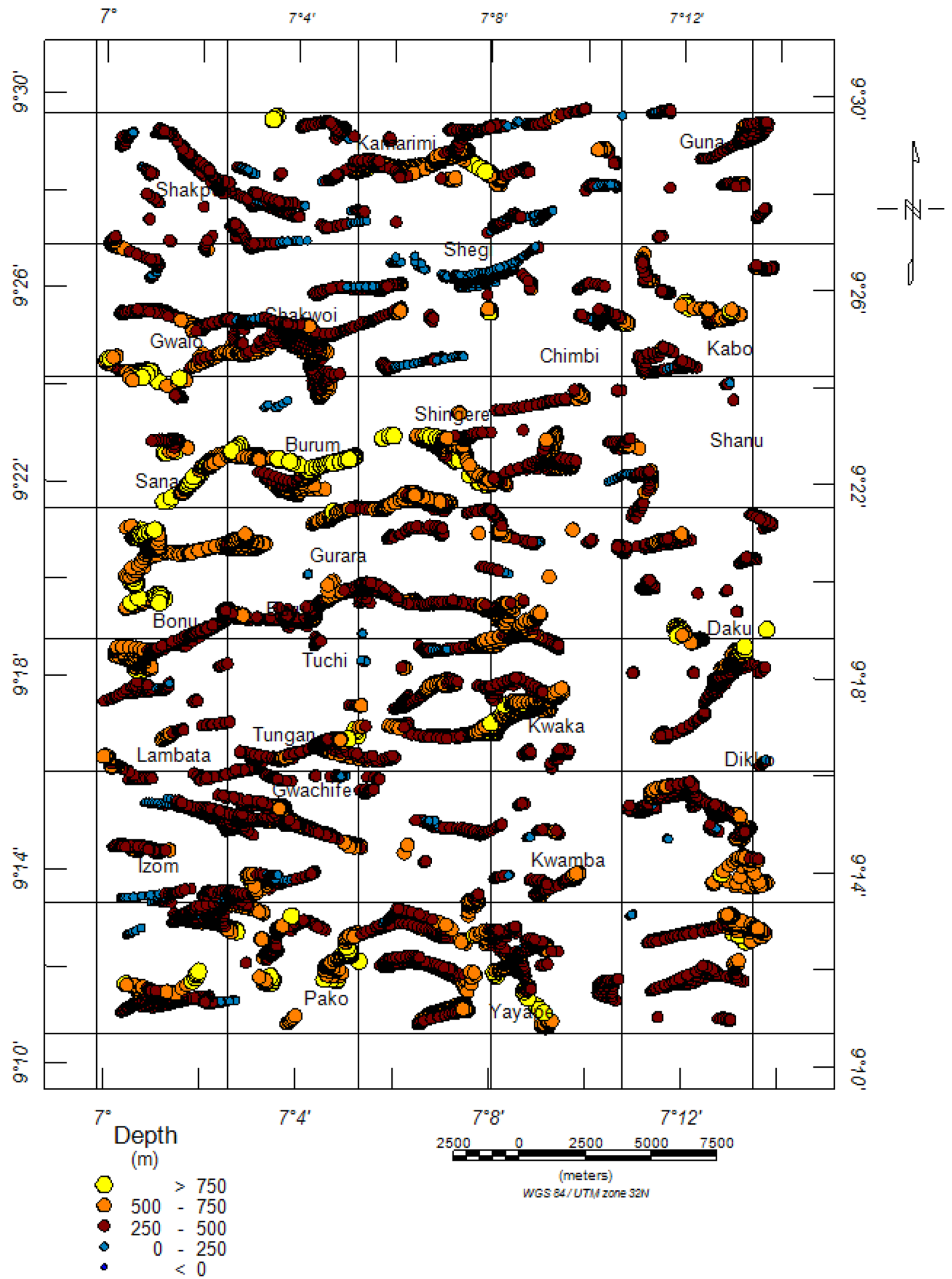

Fig. 8 Map of Euler solutions for structural index $N=1.0$

is well accentuated on this map. This shear/fracture zone occurs around Sana, Burum, Shingere, Gurara and Bonu in the northcentral part of the map at depths $427.96 \mathrm{~m}$ and $<607.61 \mathrm{~m}$ and aerial extent of $15.5 \mathrm{~km}$ by $6.5 \mathrm{~km}$ (Fig. 8). The observed dextrally sensed shearing in part of the Kushaka schist belt is consistent with the crustal 


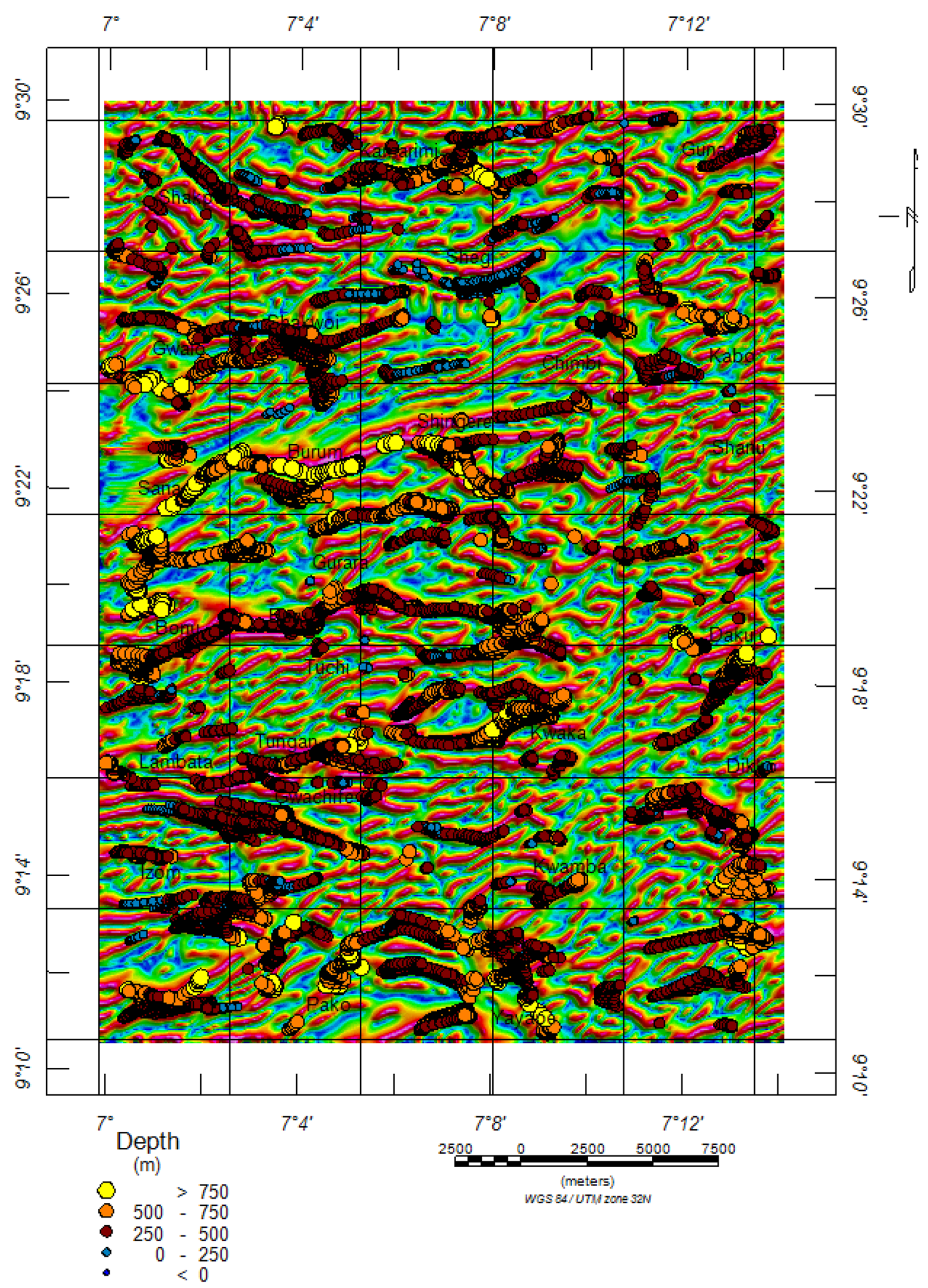

Fig. 9 Map overlay of Euler solutions $(\mathrm{SI}=1.0)$ and tilt-angle of the total horizontal derivative 
movement pattern expected by the Pan-African crustal thinning $[28,39]$. It is widely known that, regions of continental crustal thinning are most prospective for orogenic gold mineralization [80]. Interestingly, areas adjoining the observed shear zones in the study area are the beehive of artisanal miners due to the endowment of gold deposits.

Around Bonu, Tuchi, Gurara, Buru, a curvilinear, region of intense deformation, which runs approximately $17 \mathrm{~km}$ across the area in the northcentral part of the study area is also observed on the Euler map. Similarly, a deep-seated, oval shaped, region of intense deformation is expressed on the Euler map around Kwaka, trending in the ENE-WSW and NW-SE directions (Fig. 9). The conjugate dextrally and sinistrally sensed fault movements at Kwaka could be attributed to fault block rotation that have taken place during Pan-African orogeny cycle [81]. Interestingly, a notable artisanal gold mine exists at Kwaka and large silicified quartz veins are seen to provide hosting for primary gold mineralization at this location.

However, a careful examination of local geology and Euler solutions $(S I=1)$ maps reveals that swarm of dykes (or faults) with ENE-WSW and NW-SE fault trends are well expressed on the dolerite rock around Shakpere, Gwalo, Kamarimi and Shegi in the northern part of the study area (Figs. 3, 9). Also, several minor faults are well expressed at many locations in the area such as Gwachife, Izom, Daku, Guna, Pako to mention but a few. It is imperative to note that some of the areas where mining activities are currently ongoing as at the time of this study are spatially related to the brittle deformation zones in the area. Hence, gold mineralization in the Gurara area is structurally controlled.

The lineaments extracted from the aeromagnetic data analysis in conjunction with the constraints by the field observations at the study area reveal the structural framework of the Gurara area (Fig. 10). The rarity of aeromagnetic-derived lineaments at the eastern part of the area suggests that there is low level of tectonic deformation on granite gneiss and migmatites. As such, this eastern part of the study area might not be a favourable site for the migration of auriferous fluids and the localization of gold deposits. The structural styles are as shown by Rose diagram in Fig. 10, explicitly E-W, ENE-WSW and NW-SE trends with ENE-WSW structural trend as the most dominant. These different structural styles observed on the structural framework map showcase that tectonic deformation events in the area were episodic, i.e. polycyclic.

The ENE-WSW trending geologic structures within the study area cohere with Kalangai-Zungeru-Ifewara fault system that intruded the Kushaka schist belt. This fault system is closely connected to the locally developed NW-SE subsidiary faults in the area (Fig. 10). This faulting set is well thought to be a conjugate transcurrent fault system of Late Pan-African brittle-ductile deformation ( $530 \mathrm{Ma})$ that host gold mineralization in the Kushaka schist belt [4].

However, Pan-African thermotectonic events Ca 650 $\mathrm{ma} \pm 150$ ma might have played a major role in the development of pathways for the remobilization and localization of gold deposits, as ninety percent $(90 \%)$ of the mines/mining pits in the area are closely associated with ENE-WSW faults (Fig. 10).

\subsection{Hydrothermal alteration map of the study area}

Figures 11,12 and 13 reveal eTh/K ratio, Kd (potassium anomalies) and $F$ parameter maps of the study area. Generally, eTh/K ratio, Kd (potassium anomalies) and $F$ parameter maps are analysed simultaneously to delineate hydrothermal alteration haloes that are closely associated with orogenic gold mineralization $[16,21]$. It is observed that anomalously high $\mathrm{Kd}(0.017-1.654)$ and $F$ parameter (0.308-1.037), as well as anomalously low eTh/K (2.308-3.143) indicate highly fractured and hydrothermally altered areas within the study area (Figs. 11, 12, 13, 14). These signatures characteristically accentuate potassium enrichment haloes that are related to the orogenic gold mineralization in the Gurara area.

Based on the characteristic signatures on these maps (Figs. 11, 12,13), the study area can be grossly grouped into two regions, the highly altered region in the south and the low hydrothermally altered region in the north. The high flux of hydrothermal-auriferous fluids that migrated through permeable brittle (faulted) rocks caused the mineralizing fluids composing of quartz, gold and magnetite to interact with the protoliths (parent rocks), i.e. meta-volcano-sedimentary rocks and granites, thereby resulting to hydrothermal alteration haloes and precipitation of auriferous fluids that are expressed at the north-central and southern parts of the study area. Adjoining gold-bearing quartz veins, the host (meta-volcano-sedimentary rocks and granites) have been hydrothermally altered to sericite-chlorite-epidote assemblages.

A closer look at the geological and potassium enrichment maps (Figs. 3, 11, 12, 13, 14), it is observed that the major lithological (where rheological contrast is significant as a result of stress and strain at the shear zone) is hydrothermally altered. This shear zone falls on the undifferentiated schist and granites rocks around Shingere, Kushashi, Gibape at the north-central part of the study area. Since geologic structures created by tectonic deformation events provide conduits through which hydrothermal mineralizing fluids can migrate and precipitate metals like gold (Figs. 3, 11, 12, 13). Hence, proximal areas to geologic structures in the north-central and southern parts of the area are prominently altered by hydrothermal fluids. As a matter of fact, ninety percent (90\%) of the areas where 


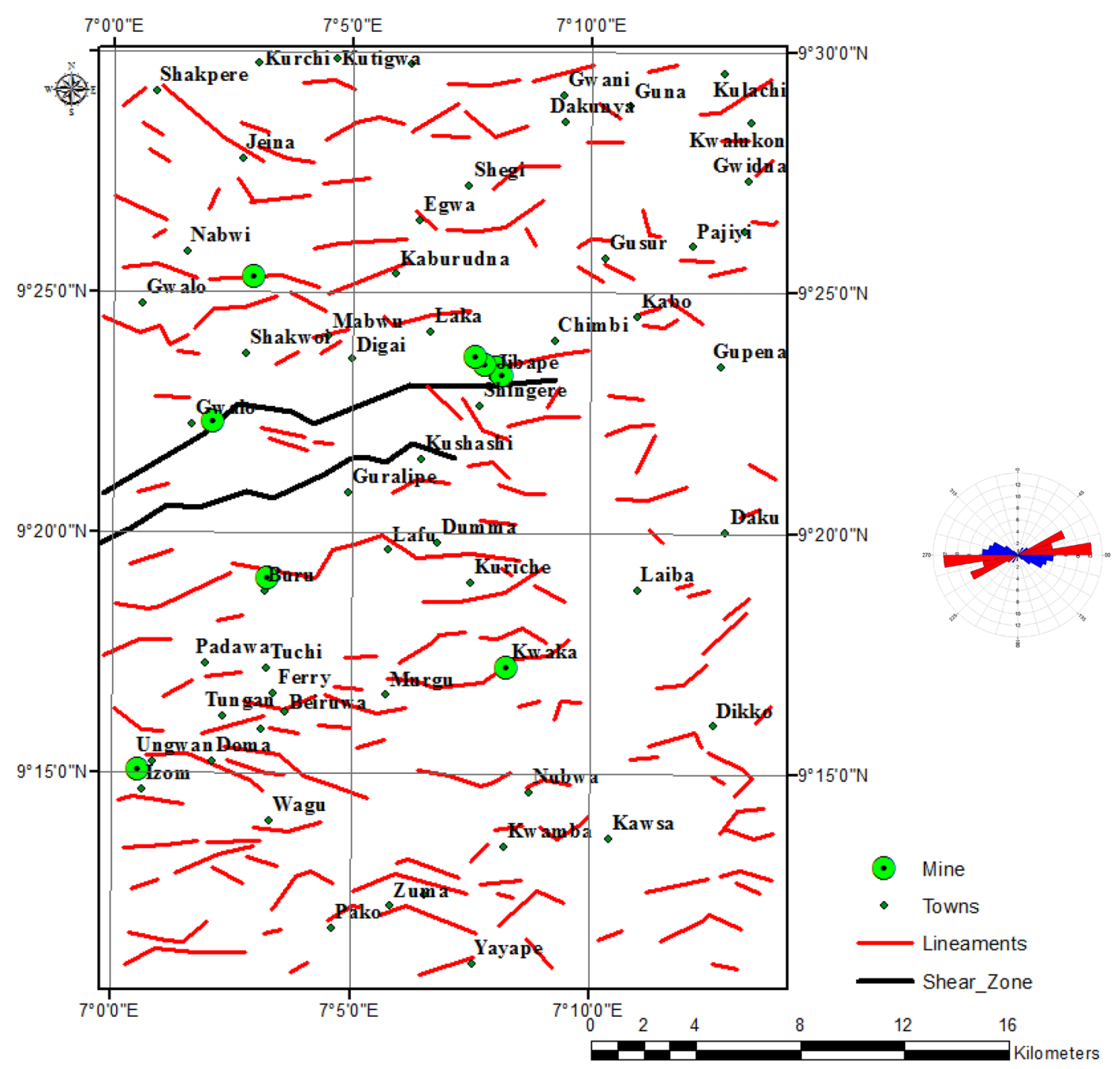

Fig. 10 Structural framework map of the study area

artisanal mining activities are currently active coincide with zones that are hydrothermally altered (Fig. 14).

It is worth noting that, the high potassium enrichment zones around Kwaka, Kwamba and Izom coincide with the signatures of high magnetic susceptibility, showing high magnetic field intensities reaching up to - 71 nT. Polymetallic mineralization occurs at the low magnetic equator where potassium enrichment values and the negative total magnetic intensities are greatest (Figs. 4, 11, 12, 13). The evidence of polymetallic mineralization observed in part of the schist belt corroborates the results of other researchers in the belt $[44,56,82]$.

Despite the presence of high faulting that are observed in the northern part of the study area, prominent expressions of extremely low $F$ parameter $(<0.308)$ and $\mathrm{Kd}$ $(<0.017)$ as well as anomalously high eTh/K values are observed around Kamarimi, Guna, Shakpere and Kabo to mention but a few places. These insignificant expressions of syn-mineralization hydrothermal alteration subsystem in the northern part of the area can be attributed to less traces of primary gold mineralization (Figs. 10, 11, 12, 13, 14).

The potassium (K) composite image map (Fig. 14) of the study area combines $\mathrm{K}$ (in red) with K/eTh (in green) and $\mathrm{K} / \mathrm{eU}$ (in blue). This map reveals the overall surface distribution of potassium concentrations in the area; thus, anomalously high concentrations of $\mathrm{K}$ can be easily distinguished on the map. The white colour on the map is characteristic of felsic rocks, specifically granites. Granites are often reflected by high concentrations of $\mathrm{K}, \mathrm{K} / \mathrm{eTh}$ and $\mathrm{K} / \mathrm{eU}$ (Figs. 3, 14). Black colour is observed on the undifferentiated schist and this corresponds to low concentrations of $\mathrm{K}$, eTh and eU. Meanwhile, a dramatic change is visibly evident at the suspected shear zone and it is reflected by 


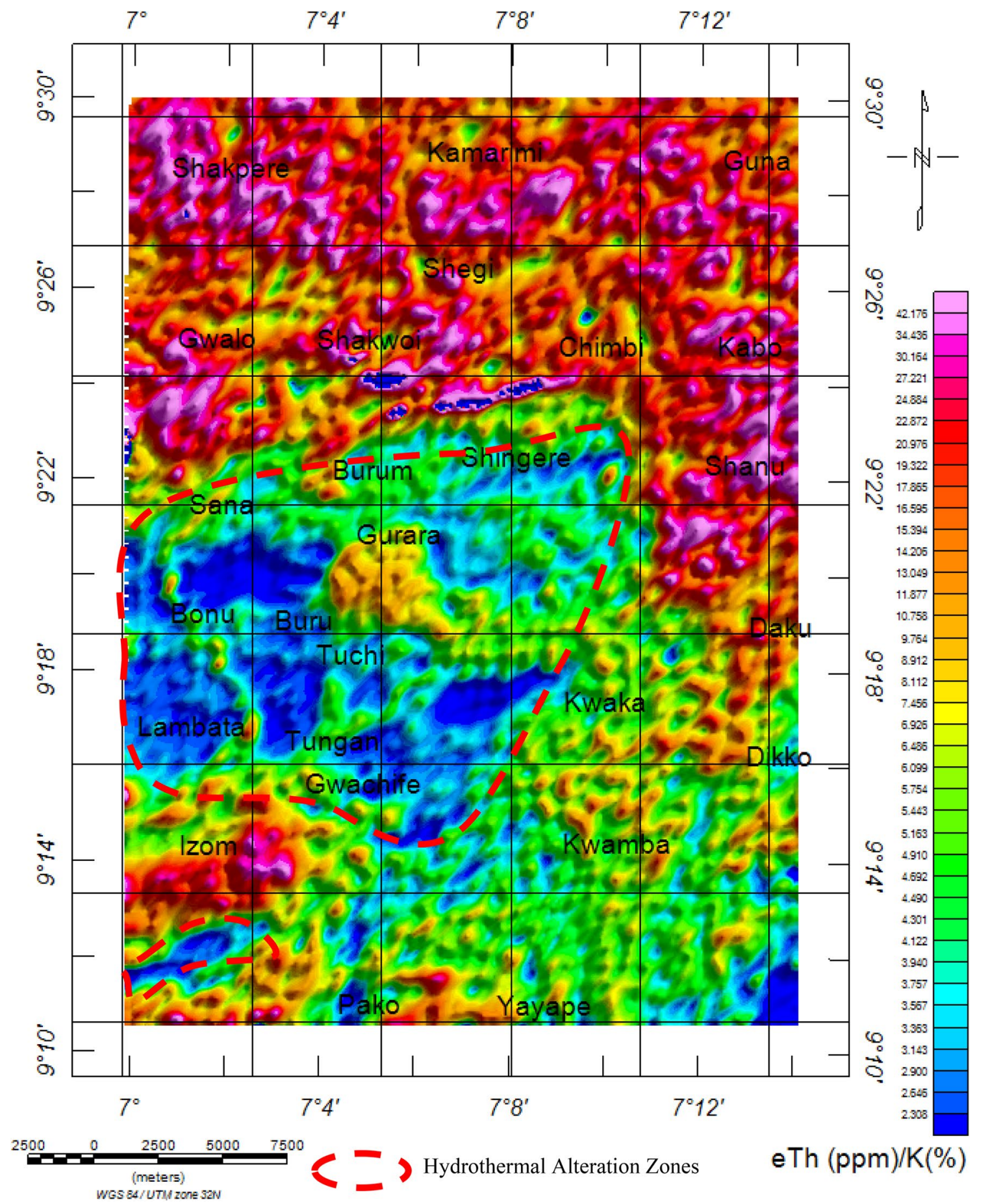

Fig. 11 Equivalent thorium/potassium (eTh/K, ppm/\%) ratio map of the study area

high concentrations of $\mathrm{K}, \mathrm{eU}$ and low eTh, as displayed in pink colour (Fig. 14).

On the K composite map, intrusion of quartz vein that runs from Guna to Lambata is displayed in pink colour with black hues, indicating that it contains relatively high concentrations of $\mathrm{K}$, eTh and eU. It is also observed on the $\mathrm{K}$ ternary map that different radiospectrometric patterns are expressed on migmatites, as its grade of metamorphism increases (Figs. 3, 14). Migmatite gneiss is characterized by high concentrations of $\mathrm{K}$, eTh and low eU as shown in tint green, whereas migmatite is outlined by relatively low concentrations of the three radioelements as shown in smoky green. It is worthy of note that, as grade of metamorphism of rocks scales 


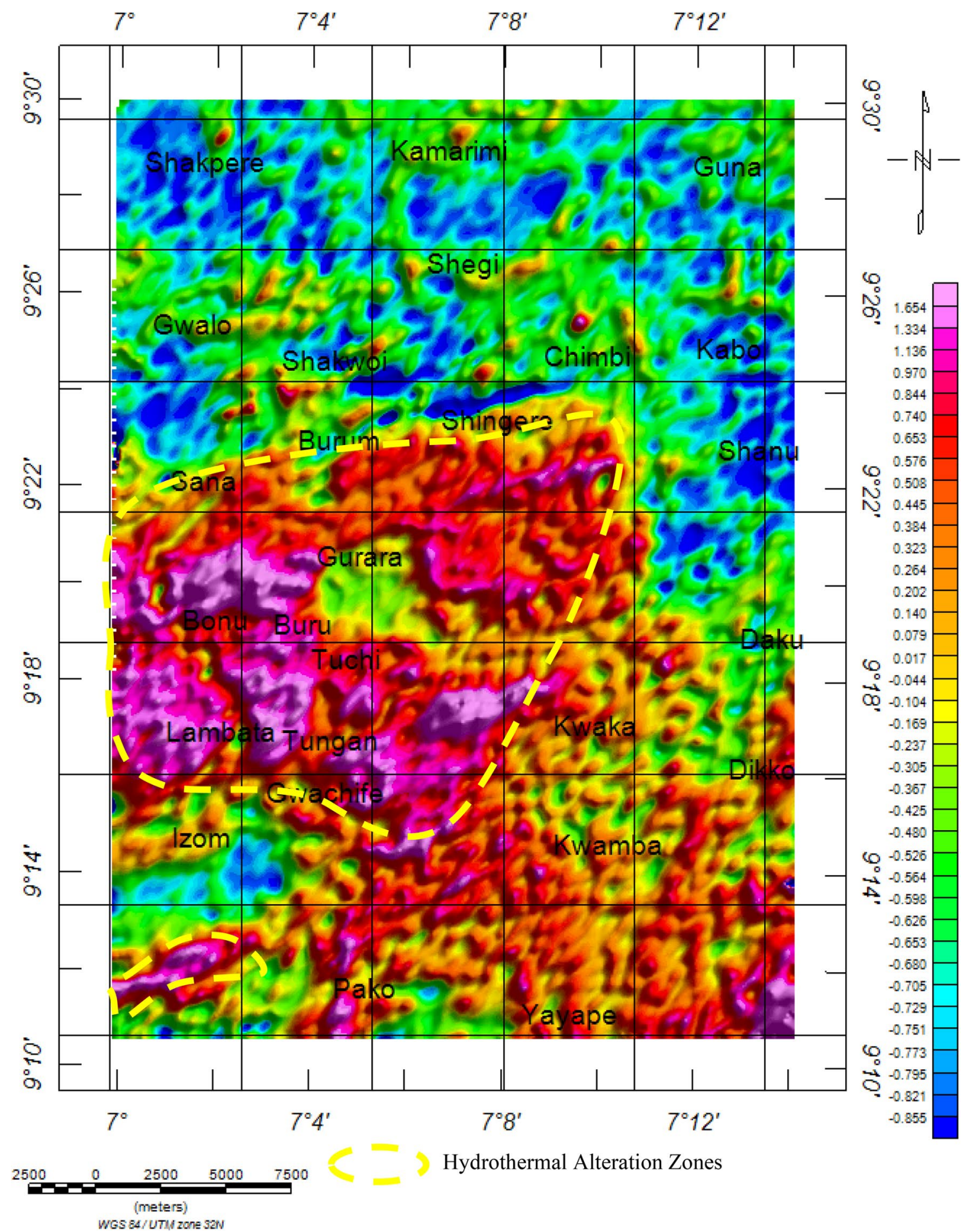

Fig. $12 \mathrm{Kd}$ of Saunders et al. [16] (potassium anomalies) of the study area

upward, the proportion of radioelements becomes more random. The distinct relationship between colour hues or tones and ternary ratio of the three radioelements allows the ternary map to showcase surface distributions of the area; thus, unraveling the surface geology, subtle structural framework and mineralized zones in this study area (Fig. 14).

As a matter of fact, the hydrothermal alteration maps (Figs. 11, 12, 13, 14) exhibit an excellent resemblance with the prevailing geologic trend (i.e. ENE-WSW) within the 


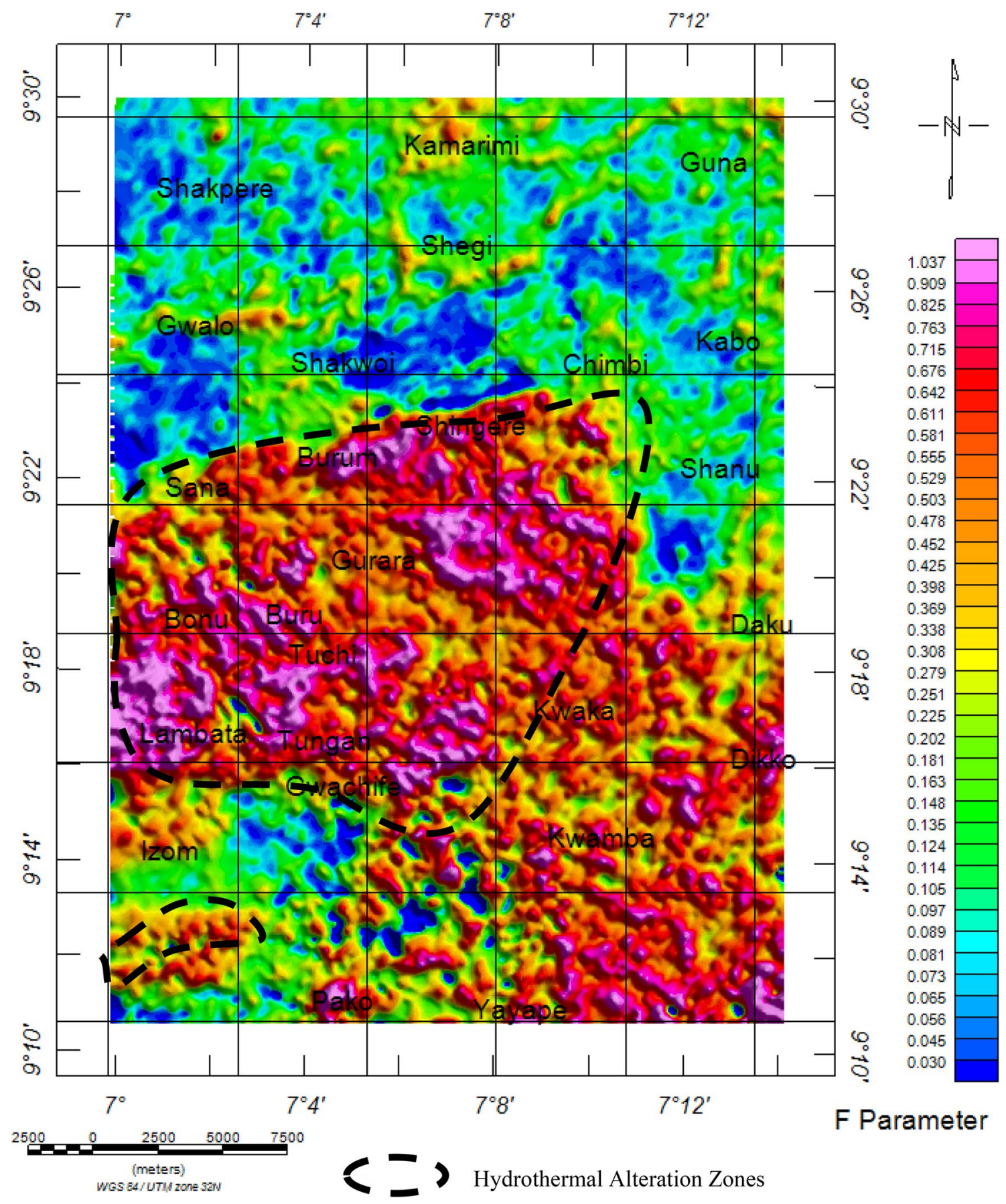

Fig. 13 F-parameter of Efmov [37] of the study area

Kushaka schist belt (Fig. 3). This is an indication that hydrothermal alteration processes could have occurred contemporaneously with the orogenic gold mineralization in the area. The hydrothermally altered zones in the Gurara area are structurally controlled and are mostly associated with structures that trend in the ENE-WSW direction and at the same time are spatially associated with some of the existing mines/mining pits and geochemical anomalies
(Fig. 14). Even though the size of hydrothermal alteration haloes might give exaggerated impressions about the economic viability of in situ gold resources in the area, it can still provide exploration vectors for prospector prior core drilling and gold assaying program.

Although presence of geologic structures constitutes the first-order control on orogenic gold mineralization in Nigeria and elsewhere in the world [3, 6-8, 20, 23, 27], 


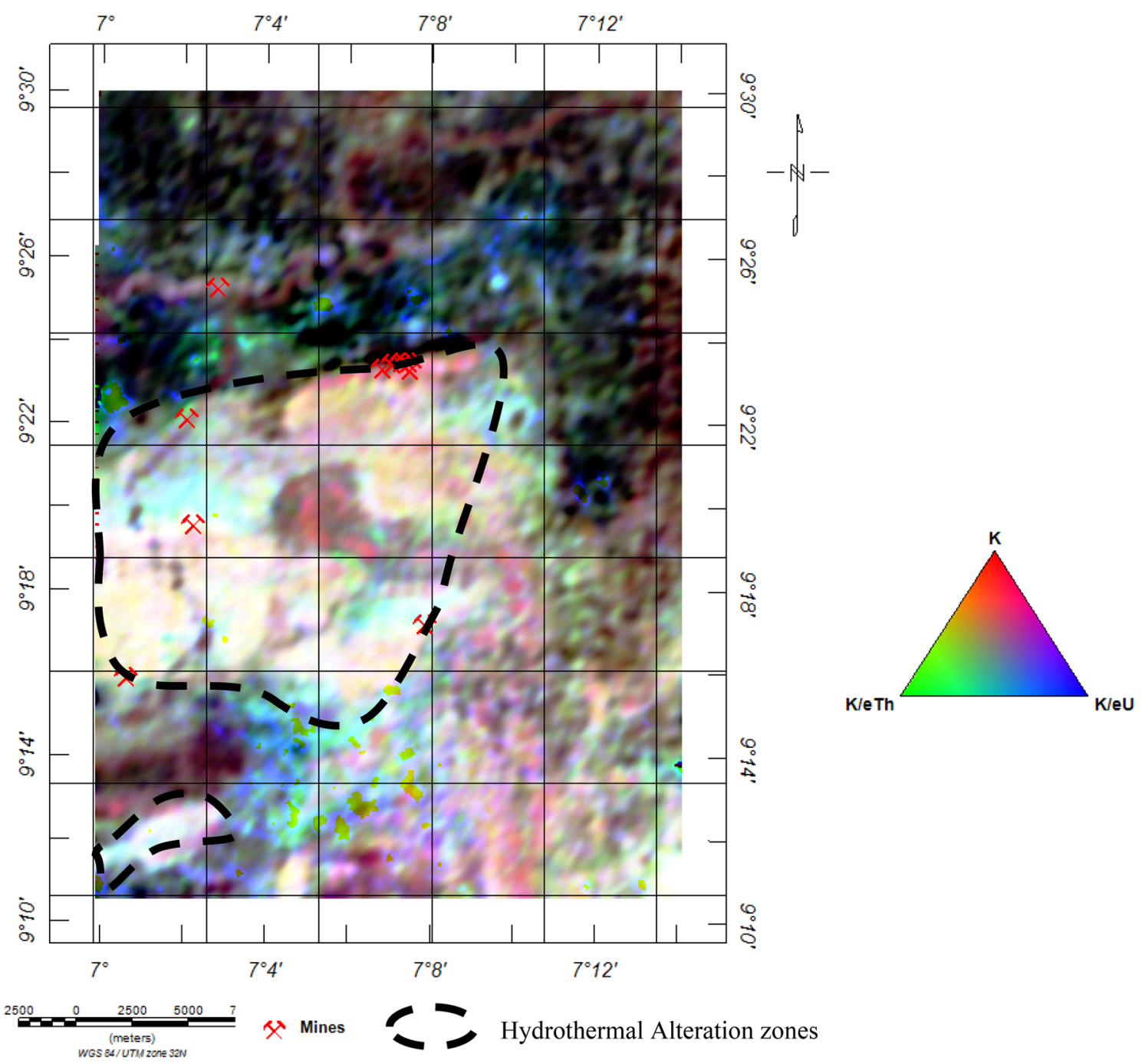

Fig. 14 Potassium ternary map of the study area

mapping of hydrothermal alteration haloes is equally important for a promising orogenic gold mineralization mapping.

\section{Conclusions}

This study has showcased the effectiveness of combined magnetic and radiometric geophysical prospecting methods in mapping structures and hydrothermal alteration haloes as related to orogenic gold mineralization in the Gurara area. The results obtained from different magnetic enhancement techniques employed in this study revealed that subsurface geologic structures that are controlling orogenic mineralization in the Gurara area trend principally in the ENE-WSW direction; others are trending in the E-W and NW-SE directions. The conjugate transcurrent faulting (i.e. ENE-WSW and NW-SE faults trend) on the structural framework map constitutes a first-order control on orogenic gold mineralization in the area, as it is spatially associated with ninety percent $(90 \%)$ of known mineralized locations in the Gurara area.

Peak magnetic anomalies with brittle-ductile deformation signatures, that trend in the ENE-WSW direction, are related to shearing and severe fracturing at the contact zone between the schist and granite bodies in the northcentral part of the Gurara area. These deep-seated, brittle-ductile shear/fracture zones with characteristic depth range of $427.96 \mathrm{~m}$ and $<607.61 \mathrm{~m}$ and aerial extent of $15.5 \mathrm{~km}$ by $6.5 \mathrm{~km}$ serve as localizer of gold deposits within the studied area.

Potassium enrichment haloes related to orogenic gold mineralization in the Gurara area showed high potassium anomalies, $\mathrm{Kd}(0.017-1.654)$ and $F$ parameter proposed by Efmov [37] (0.308-1.037), as well as anomalously low eTh/K (2.308-3.143). These hydrothermally altered zones in the 
study area are closely associated with geologic structures and as well as known auriferous mineralized locations. The zones of high potassium enrichment around Kwaka, Kwamba and Izom in the investigated area coincide with the signatures of high magnetic susceptibility, which showed high negative total magnetic field intensities reaching up to $-71 \mathrm{nT}$. Polymetallic mineralization in the low magnetic equator latitudes occurs where potassium enrichment value and total magnetic intensities (trough) are greatest.

Thus, areas with evidences of faulting and hydrothermal alteration are potential zones for orogenic gold mineralization within the Kushaka schist belt; petrographic and $\mathrm{X}$-ray diffraction studies, coring and geochemical exploration program should be focused to these zones mapped in the study area.

\section{Compliance with ethical standards}

Conflict of interest On behalf of all authors, the corresponding author states that there is no conflict of interest.

\section{References}

1. Ejepu JS, Unuevho Cl, Ako TA, Abdullahi S (2018) Integrated geosciences prospecting for gold mineralization in Kwakuti, North-Central Nigeria. J Geol Min Res 10(7):81-94. https://doi. org/10.5897/JGMR2018.0296

2. Obaje NG (2009) Geology and mineral resources of Nigeria. Springer, Dordrecht

3. Ajakaiye DE, Hall DH, Ashiekaa JA, Udensi EE (1991) Magnetic anomalies in the Nigerian continental mass based on aeromagnetic surveys. Tectonophysics 192(1):211-230

4. Garba I (2000) Origin of Pan-African mesothermal gold mineralization at Bin-Yauri, Nigeria. J Afr Earth Sci 31(2):433-449

5. Abubakar YI (2012) An integrated technique in delineating structures: a case study of the Kushaka schist belt Northwestern Nigeria. Int J Appl Sci Technol 2(5):164-173

6. Almasi A, Yousefi M, Carranza EM (2017) Prospectivity analysis of orogenic gold deposits in Saqez-Sardasht Goldfield, Zagros Orogen, Iran. Ore Geol Rev. https://doi.org/10.1016/j.orege orev.2017.11.001

7. Cunha LO, Dutra AC, Costa AB (2017) Use of radiogenic heat for demarcation of hydrothermal alteration zones in the Pernambuco-Brazil. J Appl Geophys 145:111-123

8. Dufrechou G, Harris LB, Corriveau L, Antonoff V (2015) Regional and local controls on mineralization and pluton emplacement in the Bondy gneiss complex, Grenville Province, Canada interpreted from aeromagnetic and gravity data. J Appl Geophys 116:192-205

9. Groves DI, Goldfarb RJ, Santosh M (2015) The conjunction of factors that lead to formation of giant gold provinces and deposits in non-arc settings. Geosci Front. https://doi.org/10.1016/j. gsf.2015.07.001

10. Groves DI, Santosh M, Goldfarb RJ, Zhang L (2018) Structural geometry of orogenic gold deposits: implications for exploration of world-class and giant deposits. Geosci Front. https://doi. org/10.1016/j.gsf.2018.01.006

SN Applied Sciences

A SPRINGER NATURE journal
11. Airo $M-L$ (2002) Aeromagnetic and aeroradiometric responses to hydrothermal alteration. Surv Geophys 23:273-302

12. Herbert S, Woldai T, Carranza EM, Van Ruitenbeek FA (2014) Predictive mapping of prospectivity for orogenic gold in Uganda. J Afr Earth Sci 99:666-693

13. Joly A, Porwal A, McCuaig TC (2012) Exploration targeting for orogenic gold deposits in the Granites-Tanami Orogen: mineral system analysis, targeting model and prospectivity analysis. Ore Geol Rev 48:349-383

14. Robb L (2005) Introduction to ore-forming processes. Blackwell Science Ltd, London, pp 166-173

15. Gaboury D (2019) Parameters for the formation of orogenic gold deposits. Appl Earth Sci. https://doi.org/10.1080/25726 838.2019.1583310

16. Saunders DF, Terry SA, Thompson CK (1987) Test of national uranium resource evaluation gamma-ray spectral data in petroleum reconnaissance. Geophysics 52(11):1547-1556

17. Almasi A, Jafarirad A, Keyrollahi H, Rahimi M, Afzal P (2014) Evaluation of structural and geological factors in orogenic gold type mineralization in the Kervian area, north-west Iran, using airborne geophysical data. Explor Geophys 45:261-270

18. Almasi A, Jafarirad A, Afzal P, Rahimi M (2015) Orogenic gold prospectivity mapping using geospatial data integration, Region of Saquez, NW of Iran. Bull Miner Res Explor 150:65-76

19. Hoover DB, Pierce HA (1990) Annotated bibliography of gamma-ray methods applied to gold exploration. U.S. Geological Survey Open-File Report:90-203

20. Maden N, Akaryali E (2015) Gamma ray spectrometry for recognition of hydrothermal alteration zones related to a low sulfidation epithermal gold mineralization (eastern pontides, NE turkiye). J Appl Geophys 122:74-85

21. de Quadros TP, Koppe JC, Strieder AJ, Costa JL (2003) Gammaray data processing and integration for lode-Au deposits exploration. Nat Resour Res 12(1):57-65

22. Akinlalu AA, Adelusi AO, Olayanju GM, Adiat KN, Omosuyi GO (2018) Aeromagnetic mapping of basement structures and mineralization characterisation of llesa Schist Belt, Southwestern Nigeria. J Afr Earth Sci 138:383-391

23. Airo $M-L$ (2007) Application of aerogeophysical data for gold exploration: implications for the central Lapland greenstone belt. Geol Surv Finl Spec Pap 44:187-208

24. Airo M-L, Mertanen S (2008) Magnetic signatures related to orogenic gold mineralization, Central Lapland Greenstone Belt, Finland. J Appl Geophys 64:14-24

25. El-Sadek MA (2009) Radiospectrometric and magnetic signatures of a gold mine in Egypt. J Appl Geophys 67:34-43. https ://doi.org/10.1016/j.jappgeo.2008.08.012

26. Shives RK, Charbonneau BW, Ford KL (1997) The detection of potassic alteration by gamma-ray spectrometry-recognition of alteration related to mineralization. In A. G. Gubins (Ed.), Proceedings of exploration 97: fourth Decennial international conference on mineral exploration, pp 741-752

27. Thomas MD, Harris JR (2009) Geological significance of highresolution aeromagnetic and radiometric data in the area of the Naver and Ste. Marie plutons, Central British Columbia: an example of remote predictive mapping (RPM). Can J Remote Sens 35(1):31-55

28. Wemegah DD, Preko K, Noye RM, Boradi B, Menyeh A, Danuor SK, Amenyoh T (2015) Geophysical interpretation of possible gold mineralization zones in Kyerano, southwestern Ghana using aeromagnetic and radiometric datasets. J Geosci Environ Prot 3:67-82

29. Salawu NB, Olatunji S, Adebiyi LS, Olasunkanmi NK, Dada SS (2019) Edge detection and magnetic basement depth of Danko area, northwestern Nigeria, from low-latitude 
aeromagnetic anomaly data. SN Appl Sci 1:1056. https://doi. org/10.1007/s42452-019-1090-3

30. Sanusi SO, Amigun JO (2020) Logistic-based translation of orogenic gold forming processes into mappable exploration criteria for fuzzy logic mineral exploration targeting in the Kushaka schist belt North-central, Nigeria. Nat Resour Res. https://doi. org/10.1007/s11053-020-09689-1

31. Amigun JO, Afolabi O, Ako BD (2012) Euler 3-D deconvolution of analytical signal of magnetic anomalies over Iron ore deposit in Okene, Nigeria. J Emerg Trends Eng Appl Sci (JETEAS) 3(4):711-717

32. Gaafar I (2015) Integration of geophysical and geological data for delineation of mineralized zones in Um Naggat area, Central Eastern Desert, Egypt. NRIAG J Astron Geophys. https://doi. org/10.1016/j.nrjag.2015.04.004

33. Abd El Nabi SH (2013) Role of $\gamma$-ray spectrometry in detecting potassic alteration associated with Um Ba'anib granitic gneiss and metasediments, G. Meatiq area, Central Eastern Desert, Egypt. Arabian J Geosci 6:1249-1261

34. Dickson BL, Scott KM (1997) Interpretation of aerial gamma ray surveys-adding the geochemical factors. J Aust Geol Geophys 17(2):187-200

35. Galbraith JH, Saunders DF (1983) Rock classification by characteristics of aerial gamma-ray measurements. J Geochem Explor 18(1):47-73

36. Gieré R, Sorensen SS (2004) Allanite and other REE-rich epidotegroup minerals. Rev Mineral Geochem 56:431-493

37. Efimov AV (1978) Multiplikativiniyj pokazatel dlja vydelenija endogennych rud aerogamma-spectrometriceskim dannym in Metody rudnoj geofiziki. Lenigrad, Naucnoproizvodstvennoje objedinenie Geofizica Ed:59-68.

38. Garba I (2003) Geochemical characteristics of mesothermal gold mineralization in the Pan-African (600 $\pm 150 \mathrm{Ma})$ basement of Nigeria. Appl Earth Sci (Trans Inst Min Metall B). https://doi. org/10.1179/037174503225003143

39. Ajibade AC, Wright JB (1989) The Togo-Benin-Nigeria Shield: evidence of crustal aggregation in the Pan-African belt. Tectonophysics 165:125-129

40. Oke SA, Abimbola AF, Rammlmair D (2014) Mineralogical and geochemical characterization of gold bearing quartz veins and soils in parts of Maru Schist belt area, Northwestern Nigeria. J Geol Res. https://doi.org/10.1155/2014/314214

41. Abubakar YI (2017) Kalangai fault system and gold/ rare metal pegmatite mineralization in the Kushaka schist, northwestern Nigeria. Dutse J Pure Appl Sci (DUJOPAS) 3(1):175-187

42. Oladapo MI, Adeoye O, Adebobuyi F, Adebobuyi FS, Badejo O, Ifarajimi W (2013) Seismic refraction study of Gurara dam phase II, Northwestern Nigeria. J Geol Min Res 5(11):239-249. https:// doi.org/10.5897/jgmr13.0180

43. Oluyide PO (1988) Structural trends in the Nigerian basement complex. In Precambrian geology of Nigeria. Geological Survey of Nigeria, Kaduna, pp 93-98

44. Garba I, Akande SO (1992) Origin and significance of CO2 bearing fluid inclusion in the Bin Yauri gold quartz veins of Northwestern Nigeria. Miner Depos 27:249-255

45. Garba I (2000) Gold prospects of the Nigeria Pan African terrain of West Africa. J Min Geol 36(2):123-135

46. Gupta AK, Singh RK, Srivastava S (2019) Investigation of auriferous mineralization over greenstone schist belt of Dhanjori Basin, Eastern India using 2D electrical resistivity tomography and induced polarisation surveys. Explor Geophys 50(4):364-375. https://doi.org/10.1080/08123985.2019.1606204

47. Garba I (1988) The variety and possible origin of the Nigerian gold mineralization. Okolom-Dogonadji and Waya veins as case studies. J Afr Earth Sci 7(7/8):981-986
48. Wyborn LAI, Heinrich CA, Jaques AL (1994) Australian Proterozoic mineral systems: essential ingredients and mappable criteria. In: Australian institute of mining and metallurgy. Annual conference, Melbourne, Proceedings, pp 109-115.

49. Knox-Robinson CM, Wyborn LAI (1997) Towards a holistic exploration strategy: using geographic information systems as a tool to enhance exploration. Aust J Earth Sci 44:453-463

50. McCuaig TC, Beresford S, Hronsky J (2010) Translating the mineral systems approach into an effective exploration targeting system. Ore Geol Rev 38:128-138

51. Joly A, Porwal A, McCuaig TC, Chudasama B, Dentith MC, Aitken ARA (2015) Mineral systems approach applied to GIS-based 2D-prospectivity modelling of geological regions: insights from Western Australia. Ore Geol Rev 71:673-702

52. Hagemann SG, Lisitsin VA, Huston DL (2016) Mineral system analysis: Quo vadis. Ore Geol Rev 76:504-522

53. Yousefi M, Kreuzer OP, Nykänen V, Hronsky JMA (2019) Exploration information systems-a proposal for the future use of GIS in mineral exploration targeting. Ore Geol Rev 111:103005. https ://doi.org/10.1016/j.oregeorev.2019.103005

54. Kreuzer OP, Yousefi M, Nykänen V (2020) Introduction to the special issue on spatial modeling and analysis of ore-forming processes in mineral exploration targeting. Ore Geol Rev 119:103391. https://doi.org/10.1016/j.oregeorev.2020.103391

55. Groves DI, Santosh M, Deng J, Wang Q, Yang L, Zhang L (2019) A holistic model for the origin of orogenic gold deposits and its implications for exploration. Miner Depos. https://doi. org/10.1007/s00126-019-00877-5

56. Garba I (2002) Late Pan-African tectonics and origin of gold mineralization and rare-metal pegmatites in the Kushaka Schist Belt, northwestern Nigeria. J Min Geol. https://doi.org/10.4314/jmg. v38i1.18768

57. Tomkins AG (2010) Windows of metamorphic sulfur liberation in the crust: implications for gold deposit genesis. Geochim Cosmochim Acta 74:3246-3259. https://doi.org/10.1016/j. gca.2010.03.003

58. Zhong R, Brugger J, Tomkins AG, Chen Y, Li W (2015) Fate of gold and base metals during metamorphic devolatilization of a pelite. Geochim Cosmochim Acta 171:338-352

59. Nigerian Geological Survey Agency (2009). Total magnetic intensity and radiometric data of Abuja and its environs (sheet 186).

60. Guo L, Meng X, Shi L (2012) Gridding aeromagnetic data using inverse interpolation. Geophys J Int 189:1353-1360. https://doi. org/10.1111/j.1365-246X.2012.05448-x

61. Briggs IC (1974) Machine contouring using minimum curvature. Geophysics 39:39-48

62. Li X, Gotze H (1999) Comparison of some gridding methods. Lead Edge 18:898-900

63. Gilbert D, Geldano A (1985) A computer programme to perform transformations of gravimetric and aeromagnetic surveys. Comput Geosci 11:553-588

64. Ndousa-Mbarga T, Fenmoue AS, Manguelle-Dicoum E, Fairhead JD (2012) Aeromagnetic data interpretation to locate buried faults in south-east Cameroon. Geophysica 48(1-2):49-63

65. Oyeniyi TO, Salami AA, Ojo SB (2016) Magnetic surveying as an aid to geological mapping: a case study from Obafemi Awolowo University campus in Ile-Ife, southwest Nigeria. Ife J Sci 18(2):331-343

66. Rajagopalan S (2003) Analytical signal vs reduction to pole: solutions for low magnetic latitudes. Explor Geophys 34:257-262

67. Li X (2008) Magnetic reduction-to-the-pole at low latitudes: observations and considerations. Lead Edge 27(8):990-1002

68. Feumoe AS, Mbarga TN, Dicoum EM, Fairhead JD (2012) Delineation of tectonic lineaments using aeromagnetic data for southeast Cameroon area. Geofizika 29(2):175-192 
69. Arisoy MO, Dikmen U (2013) Edge detection of magnetic sources using enhanced total horizontal derivative of the tilt angle. Bull Earth Sci Appl Res Cent Hacet Univ 34(1):73-82

70. Cooper GJ, Cowan DR (2008) Edge enhancement of potentialfield using normalized statistics. Geophysics 73(3):H1-H4

71. Ferreira FF, de Castro LG, Bongiolo AS, de Souza J, Romeiro MT (2011) Enhancement of the total horizontal gradient of magnetic anomalies using tilt derivatives: part II-application to real data. SEG Technical Program Expanded Abstracts, pp 887-891

72. Geosoft (2009) Grav/Mag interpretation. Montaj extension developed by Geosoft (Electronic version); Oasis Montaj Data Processing Analysis (DPA) system for Earth sciences applications. Euro Technologies

73. Thompson DT (1982) EULDPH- A new technique for making computer-assisted depth estimates from magnetic data. Geophysics 47:31-37

74. Reid AB, Allsop JM, Granser H, Millett AJ, Somerton IW (1990) Magnetic interpretation in three dimensions using Euler deconvolution. Geophysics 55(1):80-91

75. Adams JS, Gasparini P (1970) Gamma ray spectrometry of rocks. Elselvier Publication Company, New York

76. Pires AB (1995) Identficacao Geofisica de areas de alteracao hidrotermal, Crixas-Guarinos, Goias. Rev Bras Geoci 25(1):61-68

77. Awoyemi MO, Hammed OS, Falade SC, Arogundade AB, Ajama OD, Iwalehin PO, Olurin OT (2017) Geophysical investigation of the possible extension of Ifewara fault zone beyond Ilesa area, southwestern Nigeria. Arabian J Geosci. https://doi.org/10.1007/ s12517-016-2813-z

78. Rattenbury MS, Vidanovich $P$ (2018) The aeromagnetic expression of New Zealand's Alpine Fault: regional displacement and entrainment of igneous rock. NZ J Geol Geophys. https://doi. org/10.1080/00288306.2018.1464031

79. Hsu SK (2002) Imaging magnetic sources using Euler's equation. Geophys Prospect 50:15-25

80. Groves DI, Bierlein FP (2007) Geodynamic settings of mineral deposit systems. J Geol Soc Lond 164:19-30

81. Oladunjoye MA, Olayinka Al, Alaba M, Adabanija MA (2015) Interpretation of high resolution aeromagnetic dta for lineaments study and occurrence of Banded Iron Formation in Ogbomoso area, southwestern Nigeria. J Afr Earth Sci. https:// doi.org/10.1016/j.afrearsci.2015.10.015

82. Akande SO, Fakorede O, Mucke A (1988) Geology and genesis of gold bearing quartz veins at Bini Yauri and Okolom in the Pan-African domain of western Nigeria. Geol Mijnb 67:41-51

83. Woakes M, Rahaman MA, Ajibade AC (1987) Some metallogenetic features of the Nigerian basement. J Afr Earth Sci 6:54-64

Publisher's Note Springer Nature remains neutral with regard to jurisdictional claims in published maps and institutional affiliations. 